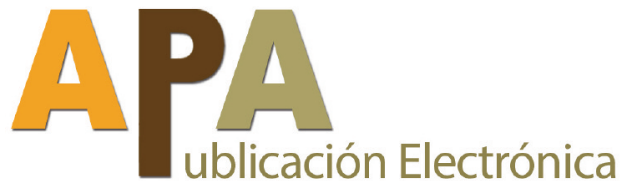

WWW 2469-0228
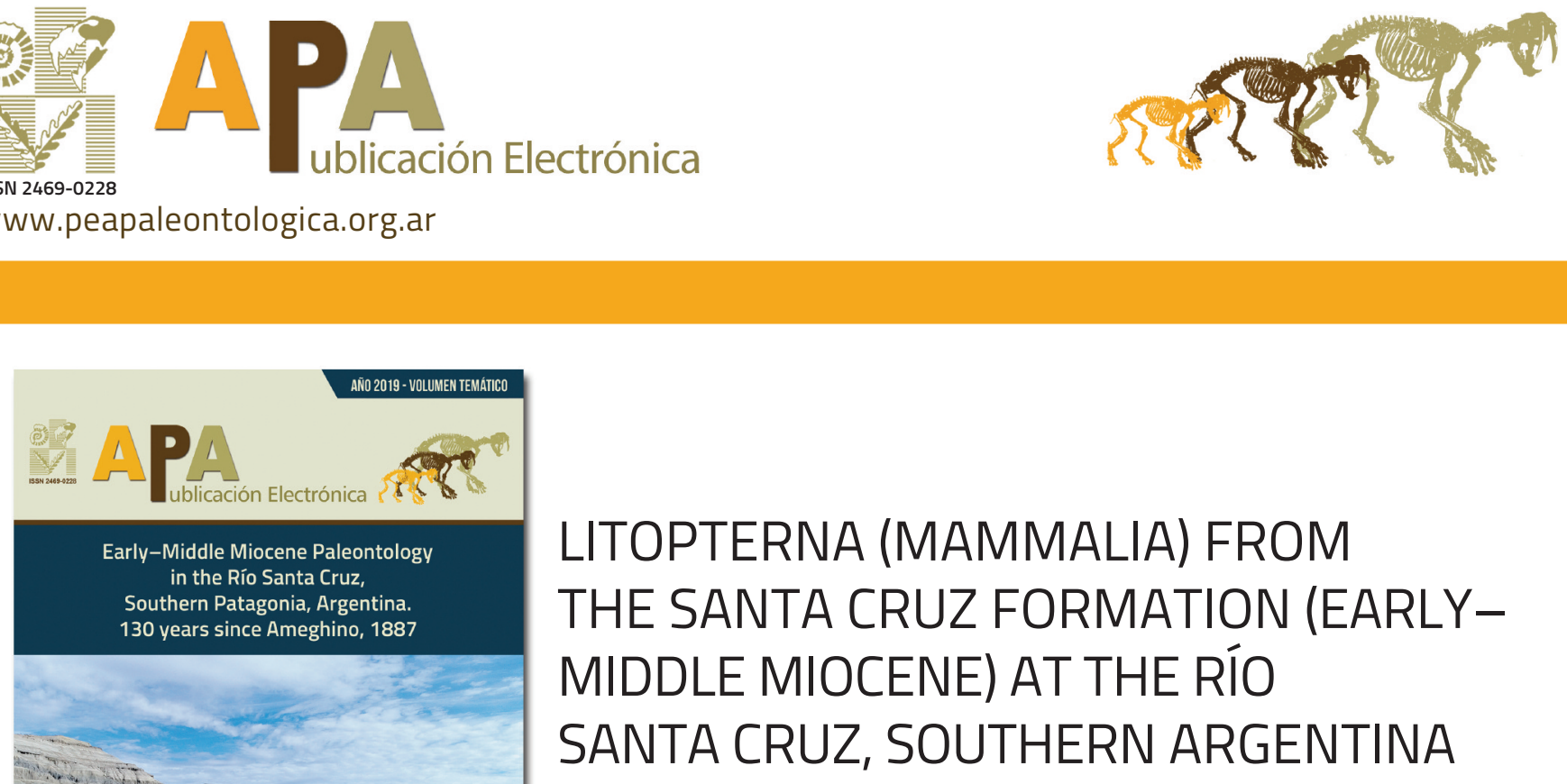

GABRIELA I. SCHMIDT ${ }^{1}$

SANTIAGO HERNÁNDEZ DEL PINO²

NAHUEL A. MUÑOZ3,4

MERCEDES FERNÁNDEZ 4,5

\begin{abstract}
'Laboratorio de Paleontología de Vertebrados, Centro de Investigación Científica y de Transferencia Tecnológica a la Producción (CICYTTP-CONICET)-Provincia de Entre Ríos, Universidad Autónoma de Entre Ríos. España 149, E3105BWA Diamante, Entre Ríos, Argentina.

2Paleontología, Instituto Argentino de Nivología, Glaciología y Ciencias Ambientales (IANIGLA, CCT-CONICET Mendoza). Av. Ruiz Leal s/n, M5500 Mendoza, Argentina. ${ }^{3}$ División Paleontología Vertebrados, Unidades de Investigación Anexo Museo, Facultad de Ciencias Naturales y Museo, Universidad Nacional de La Plata. Av. 60 y 122, B1904 La Plata, Argentina.

¿Universidad Nacional de Luján, Departamento de Ciencias Básicas. Ruta 5 y Av. Constitución, 6700 Luján, Buenos Aires, Argentina.

5División Paleontología de Vertebrados, Museo Argentino de Ciencias Naturales "Bernardino Rivadavia". Av. Ángel Gallardo 470, C1405DRJ Ciudad Autónoma de Buenos Aires, Argentina.
\end{abstract}

Recibido: 29 de marzo 2019 - Aceptado: 13 de agosto 2019

Para citar este artículo: Gabriela I. Schmidt, Santiago Hernández Del Pino, Nahuel A. Muñoz, and Mercedes Fernández (2019). Litopterna (Mammalia) from the Santa Cruz Formation (Early-Middle Miocene) at the Río Santa Cruz, Southern Argentina. Publicación Electrónica de la Asociación Paleontológica Argentina 19 (2): 170-192.

Link a este artículo: http://dx.doi.org/10.5710/PEAPA.13.08.2019.290

Desplazarse hacia abajo para acceder al aRTículoAsociación Paleontológica Argentina Maipú $6451^{\circ}$ piso, C1006ACG, Buenos Aires

República Argentina

Tel/Fax (54-11) 4326-7563

Otros artículos en Publicación Electrónica de la APA 19(2): Web: www.apaleontologica.org.ar

\section{P. Muzzopappa}

CALYPTOCEPHALELLA (ANURA, AUSTRALOBATRACHIA) REMAINS FROM RÍO SANTA CRUZ (EARLY-MIDDLE MIOCENE, SANTA CRUZ FORMATION), SANTA CRUZ PROVINCE, ARGENTINA

\section{M.S. Bargo et al.}

EARLY MIOCENE SLOTHS (XENARTHRA, FOLIVORA) FROM THE RÍO SANTA CRUZ VALLEY (SOUTHERN PATAGONIA, ARGENTINA). AMEGHINO, 1887 REVISITED

\section{R.F. Kay, J.M.G. Perry}

NEW PRIMATES FROM THE RÍO SANTA CRUZ AND RÍO BOTE (EARLY-MIDDLE MIOCENE), SANTA CRUZ PROVINCE, ARGENTINA 


\title{
LITOPTERNA (MAMMALIA) FROM THE SANTA CRUZ FORMATION (EARLY-MIDDLE MIOCENE) AT THE RÍO SANTA CRUZ, SOUTHERN ARGENTINA
}

\author{
GABRIELA I. SCHMIDT, SANTIAGO HERNÁNDEZ DEL PINO², NAHUEL A. MUÑOZ3,4, AND MERCEDES FERNÁNDEZ4,5
}

'Laboratorio de Paleontología de Vertebrados, Centro de Investigación Científica y de Transferencia Tecnológica a la Producción (CICYTTP-CONICET)-Provincia de Entre Ríos, Universidad Autónoma de Entre Ríos. España 149, E3105BWA Diamante, Entre Ríos, Argentina. gschmidt@cicyttp.org.ar

2Paleontología, Instituto Argentino de Nivología, Glaciología y Ciencias Ambientales (IANIGLA, CCT-CONICET Mendoza). Av. Ruiz Leal s/n, M5500 Mendoza, Argentina. stgo86@gmail.com

${ }^{3}$ División Paleontología Vertebrados, Unidades de Investigación Anexo Museo, Facultad de Ciencias Naturales y Museo, Universidad Nacional de La Plata. Av. 60 y 122, B1904 La Plata, Argentina.nahuelmunoz@fcnym.unlp.edu.ar

4Universidad Nacional de Luján, Departamento de Ciencias Básicas. Ruta 5 y Av. Constitución, 6700 Luján, Buenos Aires, Argentina. mechi_985@hotmail.com 5División Paleontología de Vertebrados, Museo Argentino de Ciencias Naturales "Bernardino Rivadavia". Av. Ángel Gallardo 470, C1405DRJ Ciudad Autónoma de Buenos Aires, Argentina.

\begin{abstract}
Litopterna from fossiliferous exposures of the Santa Cruz Formation (Early-Middle Miocene) along the Río Santa Cruz, Patagonia Argentina, are analyzed and described. In the prospected localities, known as Barrancas Blancas (Estancia Aguada Grande and Estancia Santa Lucía) and Segundas Barrancas Blancas (Estancia Cordón Alto and Estancia El Tordillo), specimens belonging to the families Proterotheriidae and Macraucheniidae were recorded. Within Proterotheriidae, the species Anisolophus australis, A. floweri, Tetramerorhinus lucarius, Te. cingulatum, Thoatherium minusculum and Diadiaphorus majusculus have been identified. Macraucheniidae are scarcer and represented by Theosodon sp. Although the systematics of litopterns of the Santa Cruz Formation requires a review, the new remains from the Río Santa Cruz reported here, as well as others recently recovered from the same unit in the Atlantic coast, will be valuable to clarify the taxonomy of this peculiar group of South American extinct ungulates.
\end{abstract}

Key words. Systematics. Proterotheriidae. Macraucheniidae. Santacrucian. Patagonia.

Resumen. LITOPTERNA (MAMMALIA) PROCEDENTES DE LA FORMACIÓN SANTA CRUZ (MIOCENO TEMPRANO-MEDIO) EN EL RÍO SANTA CRUZ, SUR DE ARGENTINA. Se analizan y describen los Litopterna provenientes de los afloramientos de la Formación Santa Cruz (Mioceno Temprano-Medio) a lo largo del Río Santa Cruz, Patagonia Argentina. En las localidades prospectadas, conocidas como Barrancas Blancas (Estancias Aguada Grande y Santa Lucía) y Segundas Barrancas Blancas (Estancias Cordón Alto y El Tordillo), se hallaron especímenes asignables a las familias Proterotheriidae y Macraucheniidae. En el caso de los Proterotheriidae se han identificado Anisolophus australis, A. floweri, Tetramerorhinus lucarius, Te. cingulatum, Thoatherium minusculum y Diadiaphorus majusculus. Los Macraucheniidae son más escasos y se encuentran representados por Theosodon sp. Si bien la sistemática de los litopternos de la Formación Santa Cruz requiere una revisión, los nuevos restos reportados aquí del Río Santa Cruz, así como otros recientemente recuperados de la misma unidad en la costa atlántica, serán valiosos para aclarar la taxonomía de este particular grupo de ungulados extintos de América del Sur.

Palabras clave. Sistemática. Proterotheriidae. Macraucheniidae. Santacrucense. Patagonia.

During much of the Cenozoic, South America was geographically isolated from other landmasses. This isolation promoted the evolution of an endemic fauna: marsupials, edentates, primates, rodents, and numerous "ungulate" groups (Flynn and Wyss, 1998). The South American native ungulates include some endemic families of "Condylarthra" and the orders Litopterna, Notoungulata, Astrapotheria,
Xenungulata, Pyrotheria, and Notopterna (Bond, 1986; Bond et al., 1995; Schmidt and Ferrero, 2014). The order Litopterna is surpassed only by Notoungulata in terms of taxonomic richness (e.g., Pascual et al., 1996; Cifelli and Guerrero, 1997; Cassini et al., 2012; Forasiepi et al., 2016). The litoptern record spans from the Early Paleocene (Bonaparte and Morales, 1997) to the Early Holocene (Tonni, 
1990; Bond, 1999; Schmidt and Ferrero, 2014), and the most abundant and diverse families of litopterns are Proterotheriidae and Macraucheniidae, the subjects of the present work.

Proterotheriids include small to medium-sized mammals traditionally compared with "tiny horses" due to the reduction of digits II and IV. This lead to a functional or even structural monodactyly, with the preservation of only the third digit in the case of Thoatherium Ameghino, 1887 (Kraglievich, 1930; Soria, 2001; Cassini et al., 2012). In the geologic history of proterotheriids spanning Late Oligocene to Late Pleistocene/Early Holocene (Luna et al., 2015; Corona et al., 2018), there occurred two major peaks of taxonomic richness in the Early and Late Miocene (Santacrucian and Huayquerian South American Land Mammal Ages (SALMAs), respectively). By the Late Pleistocene/Early Holocene, the number of species had declined to two taxa: Neolicaphrium recens Frenguelli, 1921 and Uruguayodon alius Corona, Perea and Ubilla, 2019 (Villafañe et al., 2006; Ubilla et al., 2011; Luna et al., 2015; Corona et al., 2019).

Macraucheniids comprise medium to large-sized forms with long necks, three-toed feet, and a complete dentition (3.1.4.3/3.1.4.3). In basal forms, such as Cramauchenia Ameghino, 1902 (Late Oligocene-Early Miocene; Dozo and Vera, 2010) or Theosodon Ameghino, 1887 (Early Miocenelate Middle Miocene; McGrath et al., 2018), the nasal aperture occupies an anterior position. In derived taxa such as Huayqueriana Kraglievich, 1934, Macrauchenia Owen, 1838 or Xenorhinotherium Cartelle and Lessa, 1988 (Late MioceneLate Pleistocene/Early Holocene; Schmidt and Ferrero, 2014), the nasal aperture has retreated to a centrodorsal position in the skull, between the orbits (Forasiepi et al., 2016). This posterior repositioning of the nasal aperture may indicate the presence of a proboscis or a similar structure, but there is no detailed anatomical study supporting this inference (Forasiepi et al., 2016).

Litopterna are conspicuous representatives of Santa Cruz Formation (Early-Middle Miocene). During the Santacrucian, Proterotheriidae have been reported to include as many as seven genera and 13 species (Villafañe et al., 2006; Ubilla et al., 2011). In contrast, Macraucheniidae is represented by one genus with several species (Scott, 1910; Croft et al., 2004; Cassini et al., 2012; Schmidt and Ferrero, 2014; McGrath et al., 2018, 2019).
Reports of Litopterna in the Santa Cruz Formation go back to the $19^{\text {th }}$ century. The first specimen of Proterotheriidae was collected by Ramón Lista in the Río Chico (Province of Santa Cruz), and studied by Burmeister (1879), who named it Anchitherium australe Burmeister, 1879 (Anchitherium Meyer, 1844 is a perissodactyl from Northern Hemisphere; Soria, 2001). Later, several field trips carried out by Carlos Ameghino in Patagonia (since 1887 to 1902; see Vizcaíno, 2011) yielded important collections of litopterns and other mammals from the Santa Cruz Formation that were studied by his brother Florentino (e.g., Ameghino, 1887, 1889, 1894, 1904a,b).

The number and variety of specimens collected in 1887 by $\mathrm{C}$. Ameghino from the Santa Cruz Formation along the Río Santa Cruz allowed F. Ameghino to name and describe the Family Proterotheriidae (Ameghino, 1887; Soria, 2001). Ameghino (1887) named five species of proterotheriids: Proterotherium cavum Ameghino, 1887, Thoatherium minusculum Ameghino, 1887, Diadiaphorus velox Ameghino, 1887, D. majusculus Ameghino, 1887, and Licaphrium parvulum Ameghino, 1887. Some of these taxa are no longer recognized as distinct (see Soria, 2001). In the case of macraucheniids, Ameghino (1887) documented the presence of Theosodon lydekkeri Ameghino, 1887. The specimens used by Ameghino to name these species should be stored at the Museo de La Plata, the institution in charge of the field trip to the Río Santa Cruz. However, in the case of proterotheriids, only two holotypes are available in that museum (MLP 12-294, $P$. cavum and MLP 12-333, D. majusculus); the remaining three have not been located (Soria, 2001). Regarding $T$. lydekkeri in the collections of the Museo Argentino de Ciencias Naturales "Bernardino Rivadavia" there is a specimen labeled as the type of the species (MACN-A 2487), but Mones (1986, p. 141) indicates that the type material of. T. Iydekkeri is lost (-). This issue deserves clarification.

In this contribution, we undertake a detailed study of new Santacrucian litoptern remains (Proterotheriidae and Macraucheniidae) recovered during fieldwork (2013-2014) along the southern banks of the Río Santa Cruz (see Fernicola et al., 2019). The prospected localities correspond to Barrancas Blancas (Estancia= Ea. Aguada Grande and Ea. Santa Lucía), Segundas Barrancas Blancas (Ea. Cordón Alto and Ea. El Tordillo), and Yaten Huageno (Ea. El Refugio) 
(Fernicola et al., 2014, 2019). The litopterns studied in this article come from the first two localities (Fig. 1); none was recovered at Yaten Huageno.

Along the Río Santa Cruz, the sediments of the Santa Cruz Formation (Burdigalian-early Langhian) are referred as a lateral continuous fluvial system across the three localities (Fernicola et al., 2014). This system shows proximal trends to the West (towards Yaten Huageno) and distal trends to the East (towards Barrancas Blancas). Regarding the amount of sediments there is also a trend according to Fernicola et al. (2014), from thinner exposures to the West (80 m; Yaten Huageno) to thicker ones to the East (170 m; Barrancas Blancas) (see Cuitiño et al., 2016, 2019 for an extensive geological description).

\section{Background for the systematics of Santacrucian Litopterns}

Ameghino (1889) described litoptern species based on specimens recovered on C. Ameghino's 1887 Río Santa Cruz expedition (Fernicola, 2011). Later, Ameghino (1891, 1894, 1902, 1904a,b, etc.) continued studying specimens of Santacrucian litopterns from other localities, recovered on succeeding trips by C. Ameghino to Patagonia until 1902 (Vizcaíno, 2011).

Mercerat (1891a), Lydekker (1894), Gaudry (1904, 1906), and Scott (1910) revised the Santacrucian proterotheriids. The anatomical and systematic study carried out by Scott (1910) deserves special attention. In his work, Scott fully described the Proterotheriidae Proterotherium Ameghino, 1883, Licaphrium Ameghino, 1887, Thoatherium, and Diadiaphorus Ameghino, 1887, although without studying the material directly and perpetuating some previous mistakes (Cassini et al., 2012). On the one hand, some of these errors were directly associated with the personal differences between $F$. Ameghino and F. Moreno (Director of Museo de La Plata in 1887). As Moreno limited the access to revise the collections of the museum, Ameghino made some erroneous taxonomic assignations, because he could not examine the type specimens. One of the most common examples is the genus Proterotherium, which included a set of species belonging to different genera. On the other hand, Scott stayed only three months in La Plata in 1901 studying the Santacrucian fossils, what prevented him to compare directly the proterotheriid specimens stored at Museo de La Plata with those in the Ameghino's personal collection (Scott, 1910; Soria, 2001). Delupi de Bianchini and Bianchini (1971) studied in detail the holotype of Proterotherium cervioides Ameghino, 1883, from the lower levels of Ituzaingó Formation (Late Miocene-Pliocene), Province of Entre Ríos. They verified that some species from the Santa Cruz Formation included in this genus belonged to one or more genera, a taxonomic issue addressed by Soria (2001).

Tauber (1999) recorded some proterotheriids from the coastal deposits of the Santa Cruz Formation at the Estancia La Costa locality (see Fernicola et al., 2019): "Proterotherium"

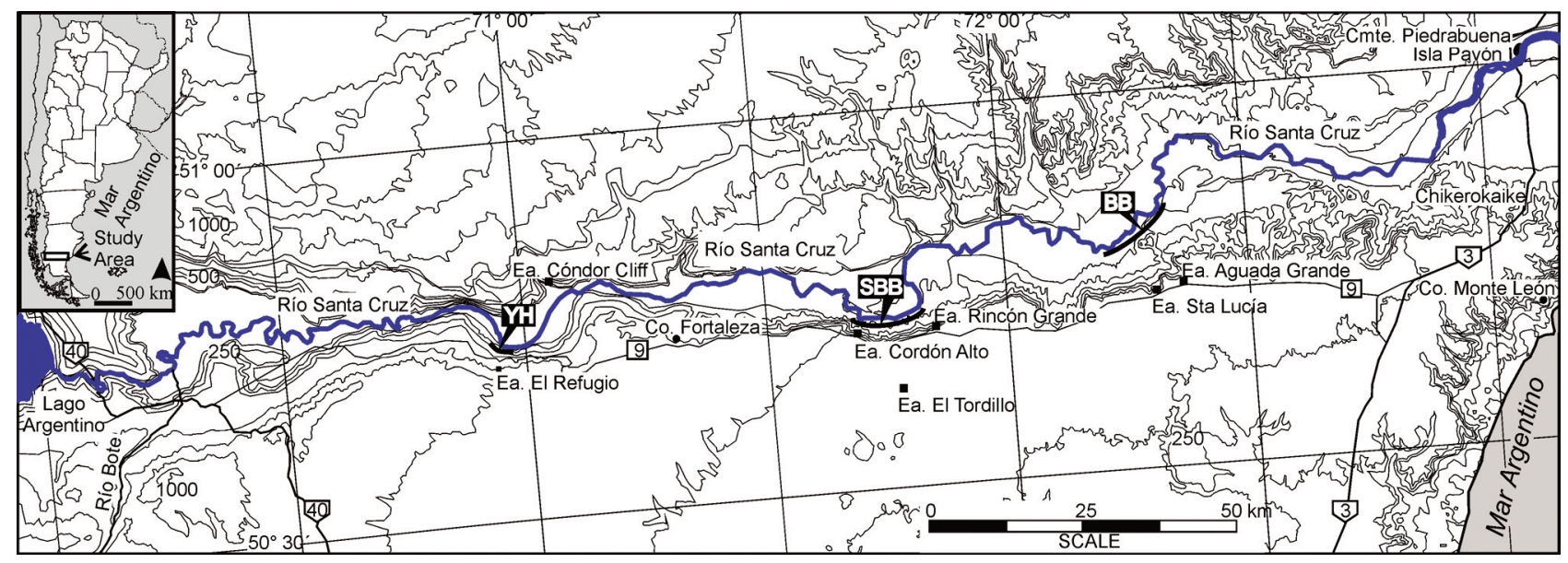

Figure 1. Map of the Río Santa Cruz with the prospected localities and estancias mentioned in the text. BB, Barrancas Blancas; SBB, Segundas Barrancas Blancas; YH, Yaten Huageno; Ea., Estancia. Modified from Fernicola et al. (2014). 
cavum; Licaphrium floweri Ameghino, 1887; Diadiaphorus robustus Ameghino, 1894; Thoatherium minusculum; Licaphrium sp.; and Diadiaphorus sp. At the Monte Tigre locality, he also recorded "Proterotherium" intermedium Ameghino, 1894 and a Proterotheriidae gen. indet. (see Fernicola et al., 2019, figs. 1 and 5 for localities).

Soria (2001) reviewed the systematics of the Proterotheriidae. For the Santacrucian levels, he recognized Tetramerorhinus lucarius Ameghino, 1894; Tetramerorhinus cingulatum (Ameghino, 1891), with two subspecies: Te. c. cingulatum (Ameghino, 1891) and Te. c. fleaglei Soria, 2001 -but Kramarz and Bond (2005) considered them at species level, restricting Te. fleaglei to the Early Miocene Pinturas Formation-; Tetramerorhinus mixtum (Ameghino, 1894); Thoatherium minusculum; Diadiaphorus majusculus; Anisolophus australis (Burmeister, 1879); Anisolophus floweri (Ameghino, 1887), and $A$. minusculus (Roth, 1899). The last taxon has also been recognized in the Collón Curá Formation, Province of Río Negro (Kramarz and Bond, 2005; Cassini et al., 2012).

Finally, Cassini et al. (2012) reported some of the taxa mentioned above (i.e., Anisolophus australis, Tetramerorhinus cingulatum, Thoatherium minusculum and Diadiaphorus majusculus) from recent collections from the Santa Cruz Formation at the Atlantic coastal localities (see Fernicola et al., 2019, fig. 5).

Following Scott (1910), the only macraucheniid recorded from the Santa Cruz Formation is Theosodon, which comprises several species: T. lydekkeri, T. lallemanti Mercerat, 1891b, T. garrettorum Scott, 1910, T. fontanae Ameghino, 1891, T. gracilis Ameghino, 1891, T. karaikensis Ameghino, 1904b (Scott, 1910), T. pozzii Kraglievich and Parodi, 1931, and T.? frenguellii Soria, 1981. Tauber (1999) recorded Theosodon lallemanti at the coastal levels of the Santa Cruz Formation, and Croft (2016) recognized the same species in the Early Miocene Chucal Formation, northern Chile, previously considered as Theosodon sp. (Croft et al., 2004). McGrath et al. (2018) described "Theosodon" arozquetai McGrath, Anaya and Croft, 2018 in the late Middle Miocene (Laventan SALMA) of Quebrada Honda, Bolivia. Another species first ascribed to Theosodon, T. hystatus Cabrera and Kraglievich, 1931, from the Arroyo Chasicó Formation (Late Miocene), Province of Buenos Aires (Argentina), was reassigned to Paranauchenia hystata (Cabrera and Kraglievich,
1931) by Schmidt and Ferrero (2014). More recently, McGrath et al. (2019) recorded the presence of Theosodon sp. in Pampa Castillo Fauna (Early Miocene, Santacrucian), Chile.

\section{MATERIALS AND METHODS}

The 42 new specimens studied are housed at Museo Regional Provincial "Padre Manuel Jesús Molina" (MPM-PV), Río Gallegos, Province of Santa Cruz, Argentina. Most remains correspond to dental and cranial elements. Taxonomic assignments were carried out through morphological and metrical comparisons with other Santacrucian specimens housed in the following institutions (Appendix 1): AMNH, American Museum of Natural History, New York, USA; FMNH, Field Museum of Natural History, Chicago, USA; MACN, Museo Argentino de Ciencias Naturales "Bernardino Rivadavia", Buenos Aires, Argentina; MLP, Museo de la Plata, La Plata, Argentina; PIMUZ, Palaeontological Institute and Museum, University of Zurich, Zurich, Switzerland; YPM-VPPU, Yale Peabody Museum, Vertebrate Paleontology Princeton University Collection, New Haven, USA.

Metrical and anatomical abbreviations. APDD, anteroposterior diameter of diaphysis; APDDA, anteroposterior diameter of distal articulation; APDO, anteroposterior diameter of olecranon; APDTu, anteroposterior diameter of tuberosity; D/d, deciduous; DC, distance between crests; DW, distal width; Fo, frontal foramina; HSC, height of the sigmoid cavity; HW, head width; L, length; LMd, length of the middle portion (between crests); M/m, upper/lower molar; NW, neck width; P/p, upper/lower premolar; SoF, supraorbital foramen; TDD, transverse diameter of diaphysis; TDDA, transverse diameter of distal articulation; TDDE, transverse diameter of distal epiphysis; TDO, transverse diameter olecranon; TDPA, transverse diameter of proximal articulation; TDPE, transverse diameter of proximal epiphysis; TDT, transverse diameter of trochlea; TDTu, transverse diameter of tuberosity; $\mathbf{W}$, width.

\section{SYSTEMATIC PALEONTOLOGY}

Order Litopterna Ameghino, 1889

Family ProterotheriIdAe Ameghino, 1887

Subfamily ProterotheriInAe Ameghino, 1887 
Type species. Anchitherium australe Burmeister, 1879. Santa Cruz Formation (Early-Middle Miocene), Province of Santa Cruz, Argentina. Referred species. Anisolophus australis (Burmeister, 1879); A. floweri (Ameghino, 1887); A. minusculus (Roth, 1899).

Anisolophus australis (Burmeister, 1879)

Figure 2.1; Table 1

List of synonymies. See Soria (2001, p. 72).

Referred material. MPM-PV 19444, left m2-m3.

Geographic distribution. Barrancas Blancas (Ea. Aguada Grande), Río Santa Cruz, Province of Santa Cruz, Argentina. Stratigraphic distribution. Santa Cruz Formation (EarlyMiddle Miocene, Santacrucian).

Description. In MPM-PV 19444 (Fig. 2.1; Tab. 1), the m2 has the paralophid longer than in $\mathrm{m} 3$, but its entoconid is smaller. The entoconid of $\mathrm{m} 3$ is separated from the hypoconulid by a small sulcus, and joined to the hypolophulid by a crest, and the hypoconulid does not form a third lobe.

Comments. The small size of MPM-PV 19444 resembles Anisolophus australis, Tetramerorhinus lucarius or Thoatherium minusculum. However, the $\mathrm{m} 3$ is different from Te. lucarius because the paralophid is short and the hypoconulid does not tend to form a third lobe. Assignment to Th. minusculum is unlikely due to the presence of entoconid in m2-m3. Moreover, MPM-PV 19444 is very similar in morphology and dimensions to MACN-A 8669, holotype of Proterotherium intermedium, a junior synonym of $A$. australis.

Anisolophus floweri (Ameghino, 1887)

Figures 2.2-4, 3.1-10; Tables 1-2

List of synonymies. See Soria (2001, p. 73).

Referred material. MPM-PV 19429, right maxillary fragment with M1 (partial), M2-M3; MPM-PV 19430, left maxillary fragment with M1 (partial), M2-M3 (without labial side); MPM-PV 19431, incomplete right upper molar (M3?); MPMPV 19432, left mandibular fragment with p3-m3; MPM-PV 19433, right p4; MPM-PV 19434, left mandibular fragment with dp4; MPM-PV 19435, right mandibular fragment with p3-m2; MPM-PV 19436, right mandibular fragment with
(1)
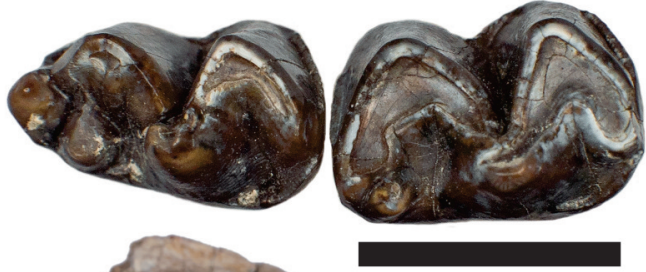

(2)

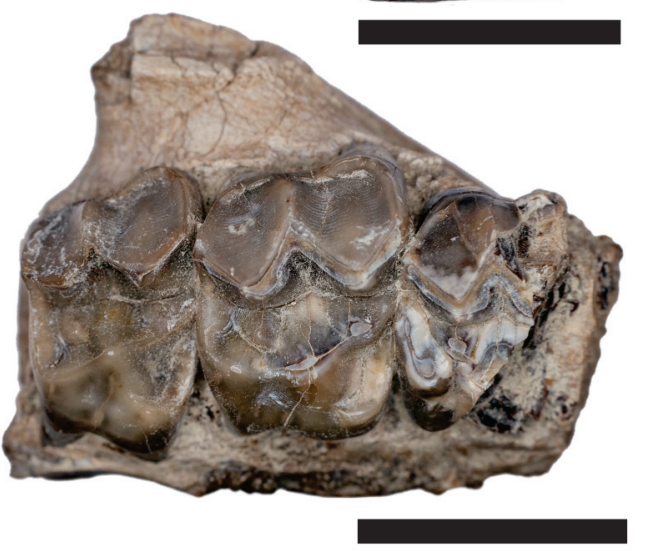

(3)

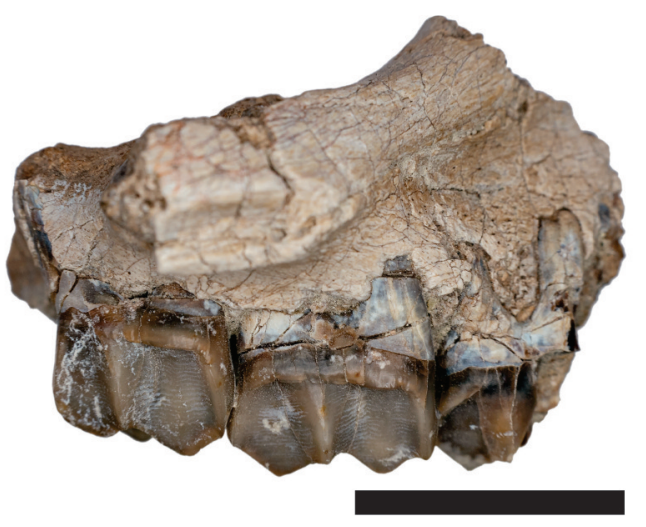

(4)

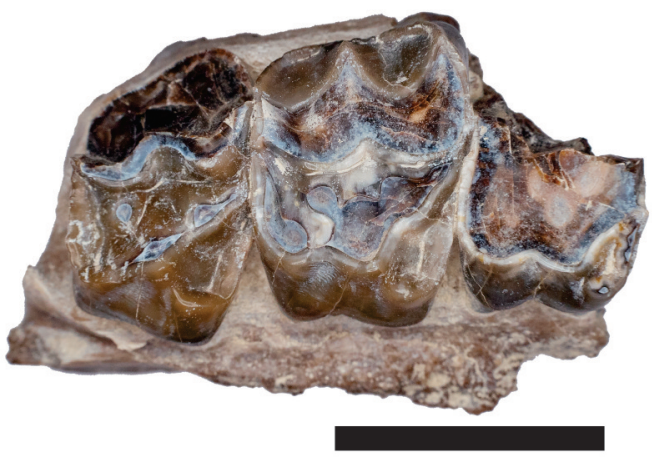

Figure 2. Anisolophus australis; 1, MPM-PV 19444, left m2-m3. Anisolophus floweri; 2-3, MPM-PV 19429, right maxillary fragment with M1 (partial), M2-M3; occlusal and labial views; 4, MPM-PV 19430, left maxillary fragment (reversed) with M1 (partial), M2-M3. Scale bars: Fig. 1= 10 mm; Figs. 2-4= 20 mm. 
TABLE 1 - Lower tooth dimensions $(\mathrm{mm})$ of the studied proterotheriid specimens

\begin{tabular}{|c|c|c|c|c|c|c|c|c|c|c|}
\hline Specimen & Taxon & & $d p 3$ & $d p 4$ & $p 2$ & p3 & $p 4$ & $m 1$ & $m 2$ & $m 3$ \\
\hline$M P M-P V$ & Anisolophus & $L$ & - & - & - & - & - & - & 12.2 & 12.7 \\
\hline 19444 & australis & $w$ & - & - & - & - & - & - & 8.4 & 7.7 \\
\hline$M P M-P V$ & Anisolophus & $L$ & - & - & - & 14.2 & 15.1 & 14.4 & 15.7 & 18.2 \\
\hline 19432 & floweri & W & - & - & - & 9.9 & 12.7 & 13.3 & 13.5 & 12.1 \\
\hline MPM-PV & Anisolophus & $L$ & - & - & - & - & 15.2 & - & - & - \\
\hline 19433 & floweri & W & - & - & - & - & 12.4 & - & - & - \\
\hline$M P M-P V$ & Anisolophus & $L$ & - & 16.0 & - & - & - & - & - & - \\
\hline 19434 & floweri & W & - & 11.5 & - & - & - & - & - & - \\
\hline MPM-PV & Anisolophus & $L$ & - & - & - & 15.24 & 13.8 & 13.61 & $16.5^{*}$ & - \\
\hline 19435 & floweri & W & - & - & - & 11.28 & 12.5 & 12.2 & 12.5 & - \\
\hline$M P M-P V$ & Anisolophus & $L$ & - & - & - & - & - & 14.12 & - & - \\
\hline 19436 & floweri & W & - & - & - & - & - & 11.03 & - & - \\
\hline$M P M-P V$ & Anisolophus & $L$ & - & - & - & - & - & 14.05 & - & - \\
\hline 19437 & floweri & $w$ & - & - & - & - & - & 11.52 & - & - \\
\hline$M P M-P V$ & Anisolophus & $L$ & - & - & - & - & 15.6 & - & - & - \\
\hline 19438 & floweri & $w$ & - & - & - & - & $10.2^{*}$ & - & - & - \\
\hline$M P M-P V$ & Anisolophus & $L$ & - & - & - & - & - & 15.0 & - & - \\
\hline 19439 & floweri & W & - & - & - & - & - & 11.5 & - & - \\
\hline$M P M-P V$ & Anisolophus & $L$ & - & - & - & - & $?$ & - & - & - \\
\hline 19440 & floweri & W & - & - & - & - & 11.4 & - & - & - \\
\hline MPM-PV & Anisolophus & $L$ & - & 14.8 & - & - & - & 14.9 & - & - \\
\hline 19441 & floweri & $w$ & - & 12.0 & - & - & - & 11.9 & - & - \\
\hline MPM-PV & Anisolophus & $L$ & - & - & - & - & - & - & - & 17.6 \\
\hline 19442 & floweri & $w$ & - & - & - & - & - & - & - & $9.9^{*}$ \\
\hline MPM-PV & Anisolophus & $L$ & - & $16.1 / 16.2$ & - & $15.2 / 15.2$ & - & $15.3 / 15.2$ & $16.3 / 16.4$ & - \\
\hline 19443 & floweri & W & - & $11.3 / 11.7$ & - & $9.9 / 10.7$ & - & $12.7 / 12.4$ & $13.4 / 13.2$ & - \\
\hline$M P M-P V$ & Diadiaphorus & $L$ & - & - & - & - & - & - & - & 19. 6 \\
\hline 19461 & majusculus & $w$ & - & - & - & - & - & - & - & 11.6 \\
\hline$M P M-P V$ & Diadiaphorus & $L$ & - & - & - & - & - & - & - & 20.3 \\
\hline 19462 & majusculus & $w$ & - & - & - & - & - & - & - & 11.1 \\
\hline$M P M-P V$ & Tetramerorhinus & $L$ & - & $13.0^{*}$ & - & - & - & - & $14.0^{*}$ & - \\
\hline 19450 & cingulatum & W & - & 11.1 & - & - & - & - & 11.3 & - \\
\hline$M P M-P V$ & Tetramerorhinus & $L$ & - & - & - & 10.8 & 11.4 & 10.4 & $11.7 / 11.7$ & $13.5^{*} / 14.1$ \\
\hline 19446 & lucarius & $W$ & - & - & - & 7.7 & 9.6 & 10.3 & $10.4 / 10.1$ & $9.4 / 9.0$ \\
\hline MPM-PV & Tetramerorhinus & $L$ & - & - & - & - & - & - & $12.6 / 12.3$ & $14.9 / 15.0$ \\
\hline 19447 & lucarius & $W$ & - & - & - & - & - & - & $10.1 / 9.9$ & $9.0 / 8.8$ \\
\hline$M P M-P V$ & Thoatherium & $L$ & - & - & 9.1 & - & - & - & - & 13.3 \\
\hline 19454 & minusculum & W & - & - & 5.1 & - & - & - & - & 7.9 \\
\hline MPM-PV & Thoatherium & $L$ & - & - & - & - & - & 10.7 & - & - \\
\hline 19455 & minusculum & $W$ & - & - & - & - & - & 8.7 & - & - \\
\hline$M P M-P V$ & Thoatherium & $L$ & - & - & - & - & 12.6 & - & 12.6 & - \\
\hline 19456 & minusculum & $w$ & - & - & - & - & 8.6 & - & 8.6 & - \\
\hline$M P M-P V$ & Thoatherium & $L$ & - & - & - & - & - & $11.8^{*}$ & 12.0 & $?$ \\
\hline 19457 & minusculum & $W$ & - & - & - & - & - & 8.2 & 8.0 & 7.4 \\
\hline$M P M-P V$ & Thoatherium & $L$ & 12.5 & - & - & - & - & - & - & - \\
\hline 19458 & minusculum & $w$ & 8.0 & - & - & - & - & - & - & - \\
\hline MPM-PV & Thoatherium & $L$ & 12.4 & 12.2 & - & - & - & 10.8 & - & - \\
\hline 19459 & minusculum & $w$ & 8.1 & 8.2 & - & - & - & 7.4 & - & - \\
\hline MPM-PV & Thoatherium & $L$ & $10.8^{*}$ & 11.3 & - & - & - & 10.9 & 12.8 & 12.4 \\
\hline 19460 & minusculum & W & 7.2 & $?$ & - & - & - & 9.5 & 8.5 & 7.7 \\
\hline
\end{tabular}

${ }^{*}$ Approximate; right/left 
root of $\mathrm{p} 4$ and $\mathrm{m} 1$ complete; MPM-PV 19437, left mandibular fragment with m1; MPM-PV 19438, left mandibular fragment with alveolus of $p 2$, roots of $p 3$, and $p 4$ almost complete; MPM-PV 19439, left fragment of m1; MPM-PV 19440, talonid of right p4; MPM-PV 19441, left mandibular fragment with talonid of dp3, dp4-m1; MPM-PV 19442, right and left m3; MPM-PV 19443, mandibular fragments with right and left p3, dp4, m1-m2.

Geographic distribution. Segundas Barrancas Blancas (Ea. Cordón Alto and Ea. El Tordillo). Río Santa Cruz, Province of Santa Cruz, Argentina.

Stratigraphic distribution of studied specimens. Santa Cruz Formation (Early-Middle Miocene, Santacrucian).

Description. The upper molars of MPM-PV 19429 (Fig. 2.2) are practically unworn (except the fragment of M1). They have shallow trigon basins, and rounded cusps. The M1$M 2$, metaconules are closer to the hypocone than to the protocone and the posterolingual groove is deeper in M1 than in M2. The M3 is unworn, lacks a hypocone and its posterior wall projects anteriorly and joins the apex of the protocone. The labial cingula are conspicuous, the styles have a moderate development, and the paracone fold is only visible labially (M2-M3, Fig. 2.3).

In MPM-PV 19430 (Fig. 2.4), the molars are more worn than in MPM-PV 19429. The fragment of M1 presents a shallow posterolingual groove, similar to that of $\mathrm{M} 2$. The $\mathrm{M} 2$ metaconule and the paraconule are rounded, and both are equidistant from the protocone, but in a more labial position. The hypocone is separated from the protocone by an enamel lagoon and a shallow posterolingual groove. The parastyle is the most developed style. In M1-M3, the anterolingual cingulum is developed and reaches the base of the protocone. The M3 lacks a hypocone.

The specimen MPM-PV 19431 is an incomplete upper molar, probably an M3 by comparison with MPM-PV 19429 and MPM-PV 19430. Its morphological and metrical similarities with the previous specimens are evident (Tab. 2), but its lingual wall is lower and not so inclined labially.

The specimens MPM-PV 19434 (Fig. 3.1), MPM-PV 19441 (Fig. 3.2) and MPM-PV 19443 (Fig. 3.3-6) preserve the dp4, more worn in MPM-PV 19441. These teeth are molariform, with well-developed paraconid and entoconid. The labial surface is rugose, the ectoflexid is pronounced, the talonid is longer than the trigonid, and the roots are thin. All of them show similar dimensions (Tab. 1).

The specimen MPM-PV 19443 (Figs. 3.3-6) consists of two poorly preserved mandibular fragments, both with the p3 erupting and dp4 in place. The broken bone allows us to observe the right p4 below the dp4 (Fig. 3.6), while the left fragment only preserves a socket. The p3s have the border of the lophids with enamel crenulations (unworn). The trigonid is shorter and narrower than the talonid. The dp4s have paraconids, shallow flexids and entoconids.

The p3-p4 of MPM-PV 19432, MPM-PV 19433, MPMPV 19435, MPM-PV 19438, and MPM-PV 19440 have entoconids. On MPM-PV 19435 (Fig. 3.7), the p3 has a well differentiated paraconid and parastylid, but on MPM-PV 19443 (Fig. 3.3) this anterior bifurcation is not so clear. The p4s show a long paralophid and the talonid longer and wider than the trigonid (Fig. 3.7-8).

The lower molars $(\mathrm{m} 1-\mathrm{m} 2)$ are massive, with shallow flexids, without paraconids, and the well-developed entoconid more lingually placed than the hypoconulid. The m3 (MPM-PV 19432, MPM-PV 19442, Fig. 3.8-10) also lacks a paraconid, the paralophid is short, and the hypoconulid is very developed.

Comments. The described specimens possess low-crowned teeth; the upper molars show a wide trigon basin, low and rounded cusps, lingual cusps (protocone and hypocone) connected on $\mathrm{M} 2$ and M3 without hypocone. The p3-m3 have entoconids; the lower molars lack paraconids, and the m3 has a hypoconulid but without the tendency to form a third lobe. These features allow us to identify these specimens as Anisolophus as distinct from Tetramerorhinus, whose characteristics are the opposite (Soria, 2001).

As mentioned before, the parastyle of M2 in MPM-PV 19430 is more developed than in other specimens and the paraconule and the metaconule are nearer to the protocone than in MPM-PV 19429, which makes this specimen closer to Tetramerorhinus than to Anisolophus; however, MPM-PV 19430 is very different from the revised specimens of Tetramerorhinus: MACN-A 11626 Te. prosistens (Ameghino, 1899)], MACN-A 8667-68 (Te. cingulatum), MACN-A 1855 (Te. lucarius), MACN-A 8663 (Te. mixtum) and MACN-PV SC 129-30 (Te. fleaglel), in which protocone and hypocone are widely separated by a groove. 
(1)
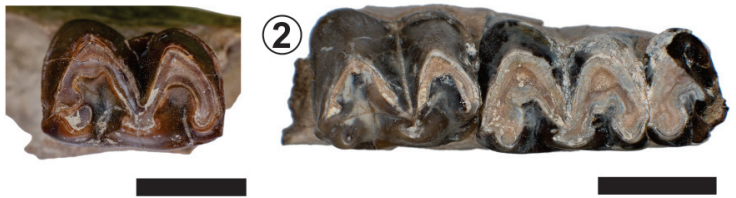

(3)

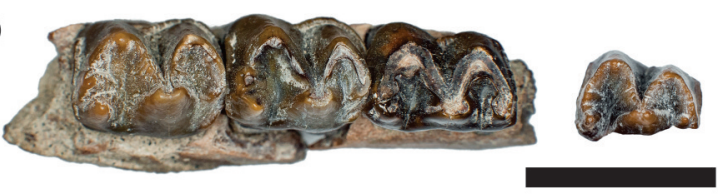

(4)

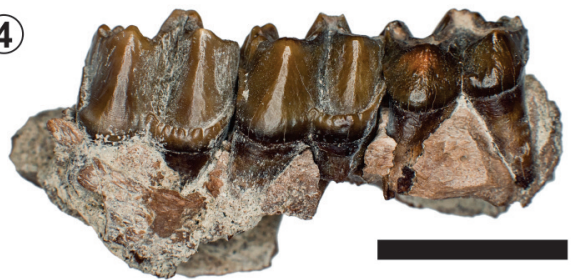

(5)
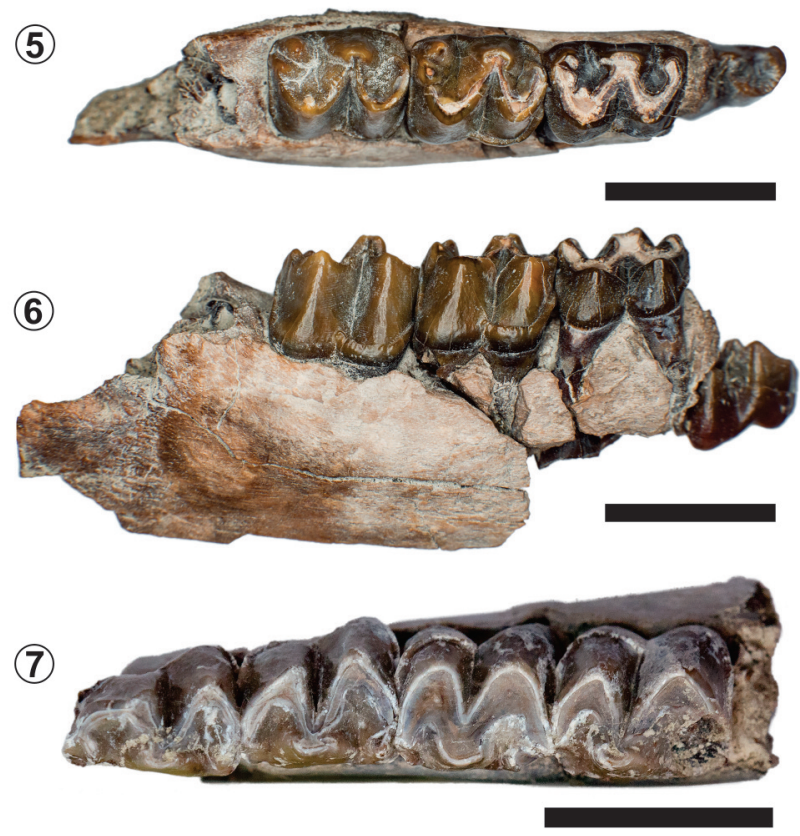

(8)

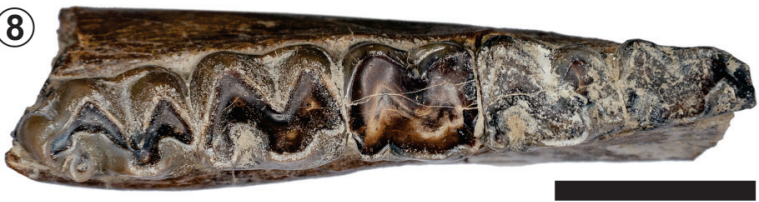

(9)

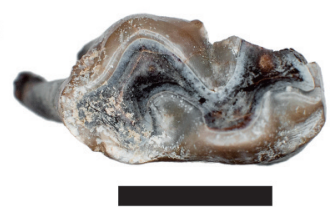

(10)

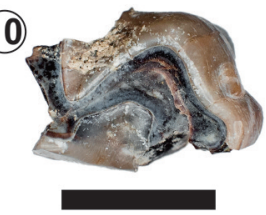

Other two taxa recognized for Santa Cruz Formation are Thoatherium minusculum and Diadiaphorus majusculus (Soria, 2001; Kramarz and Bond, 2005; Villafañe et al., 2006; Cassini et al., 2012). Our specimens are distinct from $T$. minusculum, which has smaller M1 and M2 and a lophoid metaconule. Diadiaphorus majusculus, instead, is the largest Santacrucian proterotheriid, and presents a bunoid metaconule, as in Anisolophus, but this cusp is closer to the metacone than to the hypocone, and the M3 has a reduced hypocone, differing in these ways from Anisolophus.

Anisolophus includes three species mainly differentiated by size (Soria, 2001: p. 72). Based on Soria's measurements, the described specimens match Anisolophus floweri (Soria, 2001: tab. 15), which is larger than A. australis and A. minusculus. Nevertheless, we include some comments about these (see below).

The specimens MPM-PV 19429 and MPM-PV 19431 share with Anisolophus floweri (MACN-A 8999) the greater development of the mesostyle on M2. In MPM-PV 19430, instead, the parastyle is more developed, similar to MACNA 9003-12 (A. floweri; Soria, 2001). In MPM-PV 19429, the posterolingual groove in $\mathrm{M} 1$ is deeper than in $\mathrm{M} 2$, and the protocone and the hypocone remain isolated. In $M 2$, both cusps are connected by a low crest similar to YPM-VPPU 15711 and MACN-A 9003-12 of A. floweri. The M3 in MPMPV 19429, MPM-PV 19431 and MPM-PV 19430 share with MACN-A 9003-12 the reduced metaconule and the posterior wall joining anteriorly the apex of the protocone.

We discard the assignment of our specimens with upper dentition to Anisolophus australis, because the M2 of MPMPV 19429 and MPM-PV 19430 has the posterolingual groove less marked than in MACN-PV 2417 (holotype of $A$. australis; Burmeister, 1879). Moreover, the posterior wall of the M3 (in MPM-PV 19429 and MPM-PV 19431) joins the

Figure 3. Anisolophus floweri; 1, MPM-PV 19434, left mandibular fragment with dp4; 2, MPM-PV 19441, left mandibular fragment with talonid of dp3, dp4-m1; 3-6, MPM-PV 19443, right and left mandibular fragments with $\mathrm{p} 3, \mathrm{dp} 4, \mathrm{~m} 1-\mathrm{m} 2$ (occlusal and labial views); 7, MPM-PV 19435, right mandibular fragment with $\mathrm{p3}-\mathrm{m} 2 ; 8$, MPM-PV 19432, left mandibular fragment with p3-m3; 9-10, MPMPV 19442, fragments of right and left m3. Scale bars: Figs. 1, 2, 9, and $10=10 \mathrm{~mm}$; Figs. $3-8=20 \mathrm{~mm}$. 
protocone at the apex, while in MACN-PV 2417 it joins the protocone at its base. MPM-PV 19429 and MPM-PV 19431 are similar to MACN-A 3107 of A. australis (G. Schmidt, pers. observation, 2015), but the cusps are less massive, and the teeth are larger.

Finally, although MPM-PV 19429 shows a significant morphological similarity with Anisolophus minusculus (MACNA 9001b; Roth, 1899) concerning the position and development of the cusps and posterolingual groove more marked in M1 than M2, its size is clearly larger (Tab. 2). For this reason, MPM-PV 19429 is assigned to A. floweri, following the size criterion of Soria (2001) to separate these species.

Regarding lower teeth, the specimen MPM-PV 19433 is much worn and its talonid is wider than the trigonid. This tooth could be a p3, by a little anterior bifurcation, but it is similar in morphology and dimension to the p4 of MPM-PV 19435 and MPM-PV 19438 (Tab. 1), so we consider it a p4. Moreover, the entoconid morphology in all of them is similar to that observed in the p4 of MACN-A 9003-12 and MACN-A 3085 of Anisolophus floweri, where this cusp appears laterally compressed and anterolingually oriented.

The condition of having a better developed entoconid on $\mathrm{m} 1-\mathrm{m} 2$ and the entoconid more lingually placed than the hypoconulid is also observed in Anisolophus floweri: MACNA 9003-12 (m1), YPM-VPPU 15309, MLP 12-289, and PIMUZ A/V 5293 (m1, see Zurita-Altamirano et al., 2019). The m3s are also similar to MACN-A 9003-12, MLP 82-IV3-3, MLP 82-IV-3-4, and YPM-VPPU 15309 of this species.

Genus Tetramerorhinus Ameghino, 1894

Type species. Tetramerorhinus fortis Ameghino, 1894. Santa Cruz Formation, Early-Middle Miocene, Province of Santa Cruz, Argentina.

Referred species. Te. lucarius Ameghino, 1894, Te. cingulatum (Ameghino, 1891), Te. mixtum (Ameghino, 1894), Te. prosistens (Ameghino, 1899), Te. fleaglei Soria, 2001.

Tetramerorhinus Iucarius Ameghino, 1894

Figures 4.1-3; Tables 1-2

List of synonymies. See Soria (2001, p. 42).

Referred material. MPM-PV 19445, left M1; MPM-PV 19446, left mandible with partial symphysis and p3-m3, and right mandibular fragment with m2-m3; MPM-PV 19447, right mandibular fragment with alveoli of p3-m1, and complete m2-m3, and left mandibular fragment with m2-m3.

Geographic distribution. Barrancas Blancas (Ea. Aguada Grande, Ea. Santa Lucía) and Segundas Barrancas Blancas (Ea. Cordón Alto). Río Santa Cruz, Province of Santa Cruz, Argentina.

Stratigraphic distribution. Santa Cruz Formation (EarlyMiddle Miocene, Santacrucian).

Description. MPM-PV 19445 (Fig. 4.1) is a small and much worn upper molar. It is wider than long (Tab. 2). The mesostyle is the most marked labial style and there are not labial folds. The anterolingual cingulum is developed, but does not reach the base of the protocone; the posterolingual groove is prominent, and separates protocone and hypocone.

The lower teeth of MPM-PV 19446 (Fig. 4.2) are more worn than in MPM-PV 19447 (Fig. 4.3), but they share the
(1)

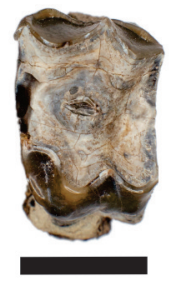

(3)

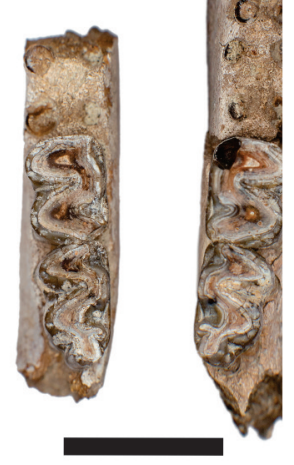

Figure 4. Tetramerorhinus lucarius; 1, MPM-PV 19445, left M1; 2, MPM-PV 19446, left mandible with partial symphysis and p3-m3, and right mandibular fragment with $\mathrm{m} 2-\mathrm{m} 3 ; 3$, MPM-PV 19447, right mandibular fragment with alveoli of $\mathrm{p} 3-\mathrm{m} 1$ and complete $\mathrm{m} 2-$ $\mathrm{m} 3$, and left mandibular fragment with $\mathrm{m} 2-\mathrm{m} 3$. Scale bars: Fig. $1=$ $10 \mathrm{~mm}$; Figs. $2-3=20 \mathrm{~mm}$. 
TABLE 2 - Upper tooth dimensions ( $\mathrm{mm}$ ) of the studied proterotheriid specimens

\begin{tabular}{|c|c|c|c|c|c|c|c|c|c|c|c|c|c|}
\hline Specimen & Taxon & & $D P 1$ & $D P 2$ & $D P 3$ & $D P 4$ & $P 1$ & $P 2$ & P3 & P4 & M1 & M2 & M3 \\
\hline \multirow{2}{*}{$\begin{array}{l}\text { MPM-PV } \\
19429\end{array}$} & \multirow{2}{*}{$\begin{array}{l}\text { Anisolophus } \\
\text { floweri }\end{array}$} & $L$ & - & - & - & - & - & - & - & - & $12.9^{*}$ & 15.8 & 12.8 \\
\hline & & w & - & - & - & - & - & - & - & - & 18.5 & 20.7 & 21.1 \\
\hline \multirow{2}{*}{$\begin{array}{l}\text { MPM-PV } \\
19430\end{array}$} & \multirow{2}{*}{$\begin{array}{l}\text { Anisolophus } \\
\text { floweri }\end{array}$} & $L$ & - & - & - & - & - & - & - & - & 14.1 & 15.6 & 13.3 \\
\hline & & w & - & - & - & - & - & - & - & - & $?$ & 22.7 & 22.3 \\
\hline \multirow{2}{*}{$\begin{array}{l}\text { MPM-PV } \\
19431\end{array}$} & \multirow{2}{*}{$\begin{array}{l}\text { Anisolophus } \\
\text { floweri }\end{array}$} & $L$ & - & - & - & - & - & - & - & - & - & - & 13.0 \\
\hline & & $w$ & - & - & - & - & - & - & - & - & - & - & $?$ \\
\hline \multirow{2}{*}{$\begin{array}{l}\text { MPM-PV } \\
19463\end{array}$} & \multirow{2}{*}{$\begin{array}{l}\text { Diadiaphorus } \\
\text { majusculus }\end{array}$} & $L$ & - & - & - & - & - & - & - & - & - & - & 16.5 \\
\hline & & w & - & - & - & - & - & - & - & - & - & - & 23.2 \\
\hline \multirow{2}{*}{$\begin{array}{l}\text { MPM-PV } \\
19448\end{array}$} & \multirow{2}{*}{$\begin{array}{l}\text { Tetramerorhinus } \\
\text { cingulatum }\end{array}$} & $L$ & - & - & - & - & - & - & - & - & 14.1 & - & - \\
\hline & & $w$ & - & - & - & - & - & - & - & - & $?$ & - & - \\
\hline \multirow{2}{*}{$\begin{array}{l}\text { MPM-PV } \\
19449\end{array}$} & \multirow{2}{*}{$\begin{array}{l}\text { Tetramerorhinus } \\
\text { cingulatum }\end{array}$} & $L$ & 12.9 & 13.3 & 14.5 & 14.3 & - & - & - & - & 15.2 & - & - \\
\hline & & w & 8.3 & 12.5 & 14.6 & 16.6 & - & - & - & - & 19.7 & - & - \\
\hline \multirow{2}{*}{$\begin{array}{l}\text { MPM-PV } \\
19445\end{array}$} & \multirow{2}{*}{$\begin{array}{l}\text { Tetramerorhinus } \\
\text { lucarius }\end{array}$} & $L$ & - & - & - & - & - & - & - & - & 11.2 & - & - \\
\hline & & $w$ & - & - & - & - & - & - & - & - & 16.9 & - & - \\
\hline \multirow{2}{*}{$\begin{array}{l}\text { MPM-PV } \\
19452\end{array}$} & \multirow{2}{*}{$\begin{array}{l}\text { Thoatherium } \\
\text { minusculum }\end{array}$} & $L$ & - & - & - & - & - & - & - & - & - & 12.7 & - \\
\hline & & w & - & - & - & - & - & - & - & - & - & 14.5 & - \\
\hline \multirow{2}{*}{$\begin{array}{l}\text { MPM-PV } \\
19453\end{array}$} & \multirow{2}{*}{$\begin{array}{l}\text { Thoatherium } \\
\text { minusculum }\end{array}$} & $L$ & - & - & - & - & $8.2 / 8.2$ & $8.8 / 8.8$ & $9.4 / 9.8$ & $9.9 / 10.3$ & $11.4 / 11.5$ & $12.1 / 12.0$ & - \\
\hline & & $w$ & - & - & - & - & $5.0 / 6.2$ & $8.9 / 8.3$ & $10.3 / 10.6$ & $11.5 / 11.4$ & $10.7^{*} / 12.3$ & $13.5 / 13.2$ & - \\
\hline \multirow{2}{*}{$\begin{array}{l}\text { MPM-PV } \\
19460\end{array}$} & \multirow{2}{*}{$\begin{array}{l}\text { Thoatherium } \\
\text { minusculum }\end{array}$} & $L$ & - & - & - & - & 7.8 & - & - & - & 11.4 & 12.6 & - \\
\hline & & $w$ & - & - & - & - & 5.9 & - & - & - & 14.8 & $?$ & - \\
\hline \multirow{2}{*}{$\begin{array}{l}\text { MPM-PV } \\
19451\end{array}$} & \multirow{2}{*}{$\begin{array}{l}\text { Thoatherium } \\
\text { minusculum }\end{array}$} & $L$ & - & - & - & - & 8.8 & - & - & - & - & - & - \\
\hline & & w & - & - & - & - & 6.6 & - & - & - & - & - & - \\
\hline
\end{tabular}

${ }^{*}$ Approximate; right/left

presence of molar paraconids and the m3 entoconid is smaller than the hypoconulid, with the latter clearly tending to form a third lobe.

Comments. MPM-PV 19445 is morphologically and metrically similar to AMNH 9245 assigned to Tetramerorhinus Iucarius (Scott, 1910: p. 75; Soria, 2001; Tab. 1). The deep posterolingual groove distinguishes MPM-PV 19445 from Anisolophus. Also, MPM-PV 19445 differs from Thoatherium minusculum because the protoloph area is square, not inclined antero-posteriorly, and its antero-posterior length is notably shorter than the bucco-labial breadth.

MPM-PV 19446 and MPM-PV 19447 are similar in size (Tab. 1) and morphology. The presence of a paraconid (particularly observable in $\mathrm{m} 2-\mathrm{m} 3$ ) and a third lobe in $\mathrm{m} 3$ are dissimilar to Anisolophus australis. A large paraconid is also present in lower molars of PIMUZ A/V 5434 assigned to Tetramerorhinus lucarius (Zurita-Altamirano et al., 2019). Likewise, despite their small size, MPM-PV 19446 and MPM-
PV 19447 do not correspond to Thoatherium minusculum because of the presence of entoconid and third lobe tendency in $\mathrm{m} 3$.

Tetramerorhinus cingulatum (Ameghino, 1891)

Figures 5.1-5; Tables 1-2

List of synonymies. See Soria (2001, p. 48).

Referred material. MPM-PV 19448, right incomplete upper molar; MPM-PV 19449, incomplete skull with left and right DP1-DP4 and M1 (right series poorly preserved); MPM-PV 19450, left mandibular fragment with dp4-m1? (poorly preserved).

Geographic distribution. Segundas Barrancas Blancas (Ea. Cordón Alto), Río Santa Cruz, Province of Santa Cruz, Argentina. Stratigraphic distribution. Santa Cruz Formation (EarlyMiddle Miocene, Santacrucian).

Description. MPM-PV 19448 (Fig. 5.1) lacks the labial side 
and roots. It is more worn than MPM-PV 19449 (Fig. 5.2-5), but the M1s are similar, as the metaconule is bunoid and a posterolingual groove is present.

In MPM-PV 19449 (Fig. 5.2), DP1-DP4 are antero-posteriorly elongated. DP1 and DP2 present only a labial cusp (paracone?) and DP2 is more labially concave. In occlusal view, both teeth are divided by a groove into two portions, the posterior being deeper and wider. The DP3 shows an intermediate morphology between premolars and molars, with all cusps present. The mesostyle is the most developed labial style (as it occurs in DP4 and M1), and the paracone and metacone folds are slightly marked. The lingual side is divided by a shallow groove and there is a weak cingulum. In DP3-DP4, protocone and hypocone are connected by a low crest. The DP4 is similar in morphology to the $M 1$, but it is narrower.

The facial region of the skull is similar in length to the braincase. In dorsal view (Fig. 5.3), fragments of the left nasal bone and the frontals are preserved. Two frontal foramina with the respective grooves (oriented to the middle line) are preserved. On the cranial vault, a sagittal crest reaches the dorsal border of the occipital. In lateral view (Fig. 5.4), the dorsal profile is straight and horizontal. The left side is better preserved, and the infraorbital foramen opens at the level of DP3. The orbit lacks the posterior region (broken) and the supraorbital foramen is present. The zygomatic arch is not preserved. Posteriorly, the infratemporal crest is present. In ventral view (Fig. 5.5), the basicranium preserves the basisphenoid and the basioccipital. On the right side, the postglenoid and the paraoccipital processes are incomplete. The occipital condyles are compressed antero-posteriorly, and a bit deformed dorsoventrally by postmortem compression. The foramen magnum dimensions are $17.5 \mathrm{~mm}$ length by $19.8 \mathrm{~mm}$ width.

The dp4 of MPM-PV 19450 lacks the trigonid. The talonid presents an acute labial side and a small entoconid. This tooth is lower than $\mathrm{m} 1$.

Comments. The presence of a posterolingual groove on the M1 of MPM-PV 19448 and MPM-PV 19449 leads us to consider them as Tetramerorhinus. In contrast, Anisolophus has the protocone and hypocone connected by a low crest (e.g., MPM-PV 19429, MPM-PV 19430, MACN-A 9003-12, see above). Regarding lower teeth, the dp4 with reduced entoconid and $\mathrm{m} 1$ with developed paraconid also agrees with Tetramerorhinus (e.g., Te. lucarius: MLP 12-250, MLP 12337, MACN-A 1859-60; Te. cingulatum: MACN-A 3106, MACN-A 8667-68; Te. mixtum: MACN-A 5987, MACN-A 3068-69). The dimensions of MPM-PV 19448, MPM-PV 19449 and MPM-PV 19450 fall within the size range of Tetramerorhinus cingulatum (data in Soria, 2001). According to the dental measurements, this species is the largest of the genus. This agrees with the mean body mass estimated by Cassini et al. (2012: tab. 14.7), for Te cingulatum, Te. lucarius and Te. mixtum, with body masses of $41.71 \mathrm{~kg}$, $29.50 \mathrm{~kg}$, and $35.06 \mathrm{~kg}$, respectively.

Genus Thoatherium Ameghino, 1887

Type species. Thoatherium minusculum Ameghino, 1887. Santa Cruz Formation, Early-Middle Miocene and Pampa Castillo Fauna (Early Miocene). Province of Santa Cruz (Argentina) and Pampa Castillo, Andes Mountains (southern Chile).

Referred species. Thoatherium minusculum Ameghino, 1887.

\section{Thoatherium minusculum Ameghino, 1887}

Figures 6.1-29, 7.1-12; Tables 1-4

List of synonymies. See Soria (2001, p. 57-58).

Referred material. MPM-PV 19451, right P1 and associated right astragalus; MPM-PV 19452, right upper molar (M2?); MPM-PV 19453, incomplete and distorted skull with right and left P1-M2 and M3 erupting; MPM-PV 19454, left fragmentary mandible with incisor alveolus, roots of $\mathrm{p} 1$, incomplete p2, and isolated m3; MPM-PV 19455, right mandibular fragment with talonid of $\mathrm{p} 3$, roots of $\mathrm{p} 4$ and $\mathrm{m} 1$; MPM-PV 19456, isolated left m2; MPM-PV 19457, left mandibular fragment with m1 (broken), m2-m3 (m3 erupting and broken); MPM-PV 19458, right dp3; MPM-PV 19459, right mandibular fragment with dp3-dp4, m1; MPM-PV 19460, right $\mathrm{P} 1$, left $\mathrm{M} 1$ and $\mathrm{M} 2$, left $\mathrm{p} 3-\mathrm{m} 3$ poorly preserved; and isolated right $\mathrm{m} 3$ (broken), associated to postcranial fragments (distal fragment of right humerus with proximal ulna and radius, two proximal fragments and distal epiphysis of Mt III with sesamoids, incomplete first phalanges and complete second phalanx).

Geographic distribution. Barrancas Blancas (Ea. Santa Lucía) and Segundas Barrancas Blancas (Ea. Cordón Alto), Río 
(1)

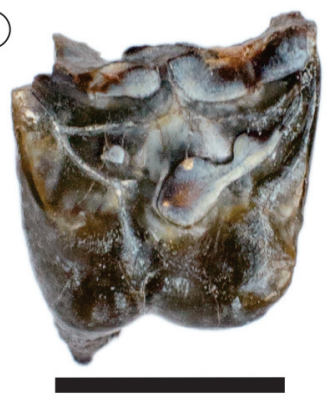

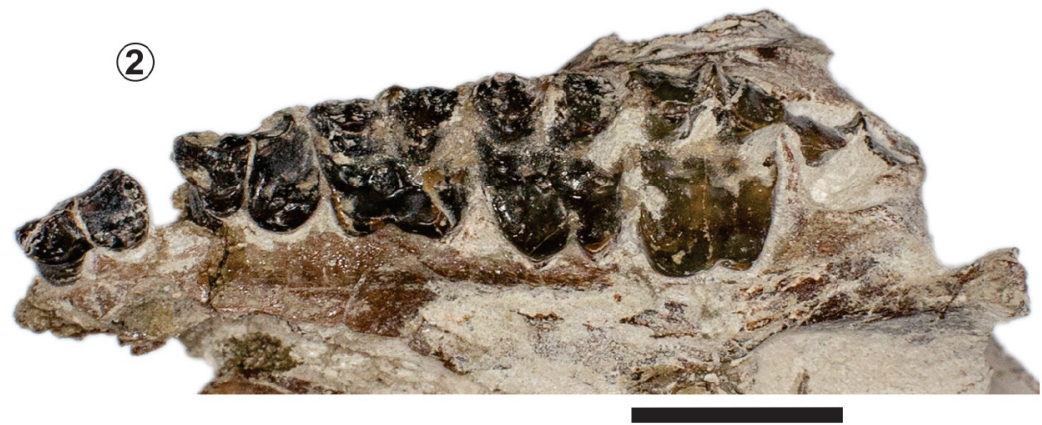

(3)

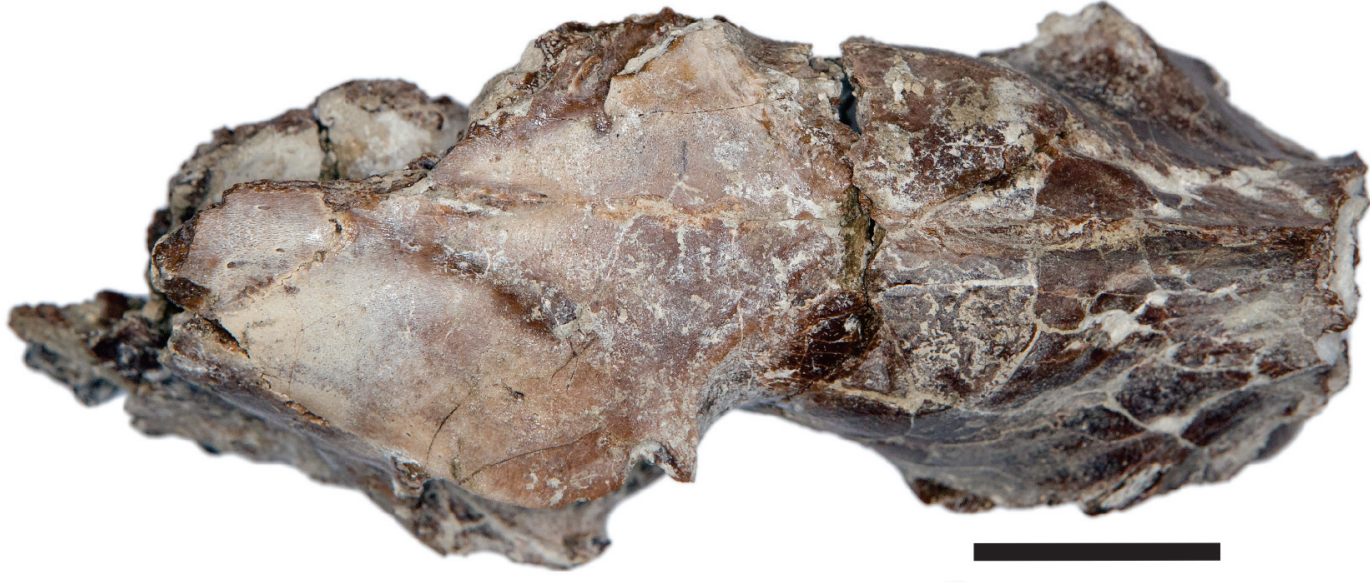

(4)

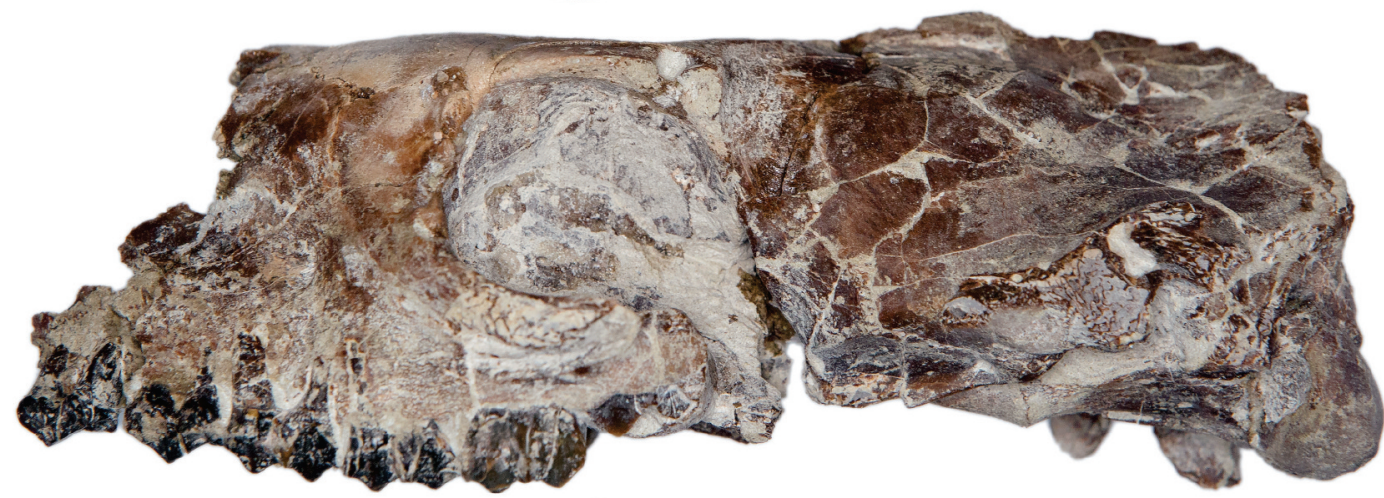

(5)

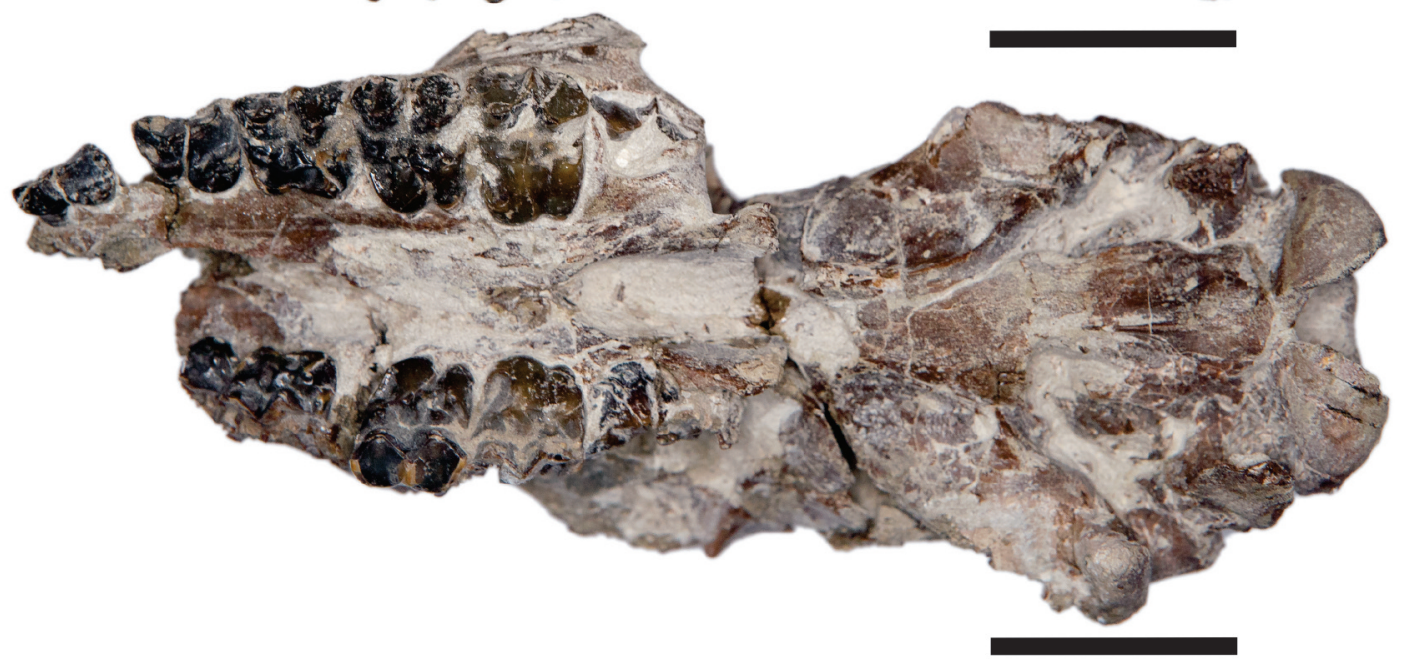

Figure 5. Tetramerorhinus cingulatum; 1, MPM-PV 19448, right incomplete upper molar; 2-5, MPM-PV 19449, incomplete skull with left and right DP1-DP4 and M1 (detail of left dental series; dorsal, lateral and ventral views). Scale bars: Fig. $1=10 \mathrm{~mm}$; Figs. $2-5=30 \mathrm{~mm}$. 

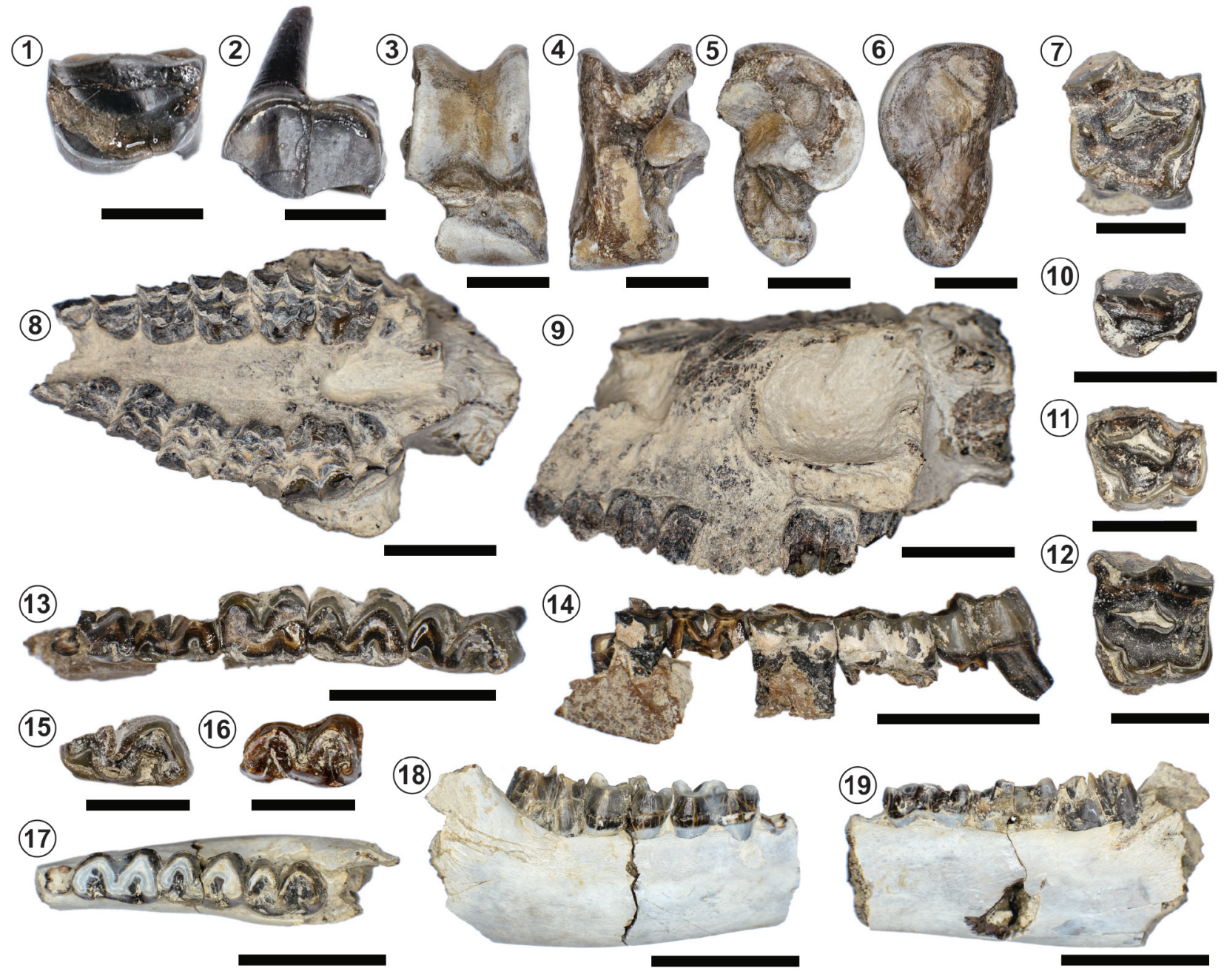

(11)

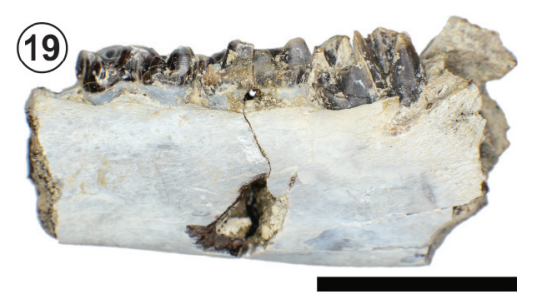

(20)
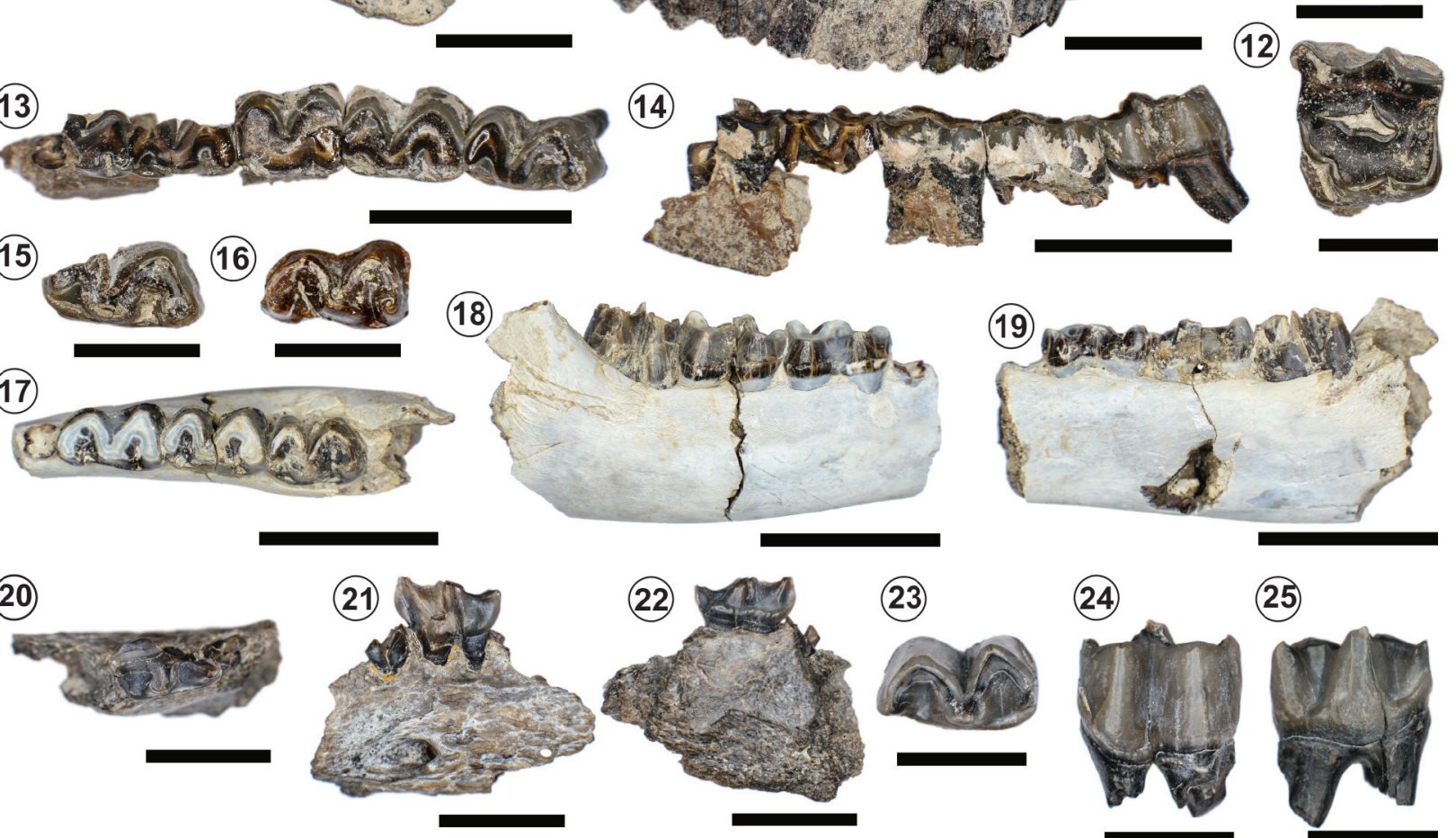

(26)

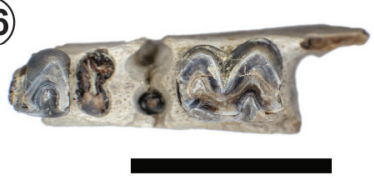

(27)

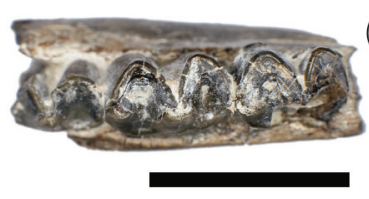

(28)

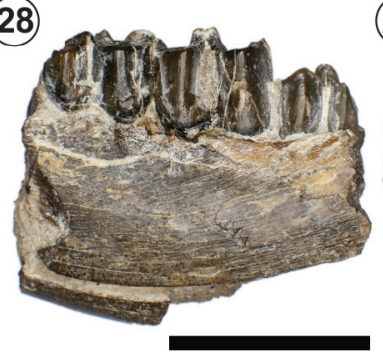

(23)

(24)

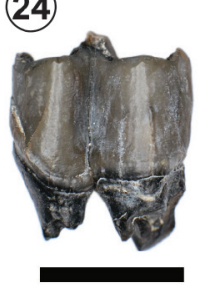

(25)

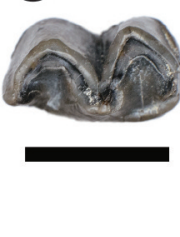

(29)

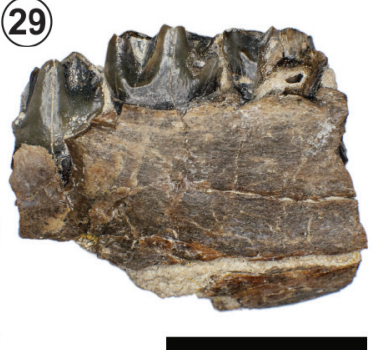

Figure 6. Thoatherium minusculum; 1-6, MPM-PV 19451, right P1 (occlusal and labial views) and associated right astragalus (dorsal, ventral, lateral and medial views); 7, MPM-PV 19452, right upper molar (M2?); 8-9, MPM-PV 19453, incomplete and distorted skull with right and left P1-M2 and M3 erupting; 10-15, MPM-PV 19460, right P1, left M1 and M2, left p3-m3 poorly preserved (occlusal and labial views; reversed); and isolated right m3 (broken); 16, MPM-PV 19458, right dp3; 17-19, MPM-PV 19459, right mandibular fragment with dp3-dp4-m1 (occlusal, labial and lingual views); 20-25, MPM-PV 19454, left fragmentary mandible with incisor alveoli, roots of p1, incomplete p2, and isolated m3 (occlusal, labial and lingual views); 26, MPM-PV 19455, right mandibular fragment with talonid of p3, roots of p4 and m1; 27-29, MPM-PV 19457, left mandibular fragment with $\mathrm{m} 1$ (broken), $\mathrm{m} 2-\mathrm{m} 3$ (m3 erupting and broken; occlusal, labial and lingual views). Scale bars: Figs. 1-7; $10-13 ; 16 ; 20-25=10 \mathrm{~mm}$; Figs. 8-9; 14-15; $17-19 ; 26-29=20 \mathrm{~mm}$. 
TABLE 3 - Astragalar dimensions (mm) of Thoatherium minusculum (MPM-PV 19451) and comparative set

\begin{tabular}{lccccc}
\hline Specimen & $L$ & $D C$ & $H W$ & NW & LMd \\
\hline $\begin{array}{l}\text { MPM-PV } \\
19451\end{array}$ & 27.1 & 13.9 & 12.8 & 11.9 & 23.6 \\
$\begin{array}{l}\text { MACN A- } \\
2974\end{array}$ & 28.8 & 15.4 & 14.5 & 12.2 & - \\
$\begin{array}{l}\text { MACN A- } \\
2983\end{array}$ & 28.0 & 14.1 & 15.0 & 11.6 & - \\
$\begin{array}{l}\text { MACN A- } \\
9048\end{array}$ & 21.5 & 13.5 & 13.4 & - & - \\
$\begin{array}{l}\text { MACN A- } \\
9049\end{array}$ & 27.3 & 15.8 & 15.0 & 12.5 & - \\
$\begin{array}{l}\text { FMNHP } \\
13193\end{array}$ & 27.3 & 14.8 & 14 & 11.5 & 21.6 \\
\hline \hline
\end{tabular}

Santa Cruz, Province of Santa Cruz, Argentina.

Stratigraphic distribution. Santa Cruz Formation (EarlyMiddle Miocene, Santacrucian).

Description. The P1 (MPM-PV 19451; Fig. 6.1-2) is labially straight and lingually rounded. The cingulum is restricted to the labial face. In occlusal view, the tooth is more worn in the posterior region. The astragalus (Fig. 6.3-6; Tab. 3) associated to P1 presents a nearly symmetrical trochlea. In dorsal view, there is a pit in the base of the neck (where the anterior tongue of the distal epiphysis of the tibia articulates). The distal articular surface is dorsoventrally convex and mediolaterally slightly convex. In ventral view, the sustentacular facet is smoothly convex and in lateral view, the ectal facet is markedly concave with a posterior convexity.

The upper molar (MPM-PV 19452; Fig. 6.7) lacks the anterolabial region. It is a worn tooth, probably an M2. In occlusal view, there are two fossettes. The antero-posteriorly elongated central one is separated from the small, rounded posterior one by a lophoid metaconule. Protocone, paraconule and hypocone are prominent. Also, there is an anterolingual cingulum that does not reach the base of the protocone.

The skull fragment MPM-PV 19453 (Fig. 6.8-9) partially preserves the maxilla and the orbits. In dorsal view, we observe fragments of the nasals, frontals and the frontal sulcus (Soria, 2001). Both dental series P1-M3 are unworn and almost complete; the M3 is not fully erupted. P1-P2 have the labial wall higher than the lingual, and a conspicuous cusp (paracone?). On the lingual side of $\mathrm{P} 2$, there is a welldeveloped anterior cusp (paraconule?), separated from a posteriorly displaced protocone by a concavity. P3-M2 are morphologically similar, increasing gradually in size; they show a reduced, lophoid metaconule that interrupts the anteroposterior groove, similar to MPM-PV 19460 (M1-M2) (Fig. 6.11-12).

The dp3s (MPM-PV 19458 and MPM-PV 19459) are very similar to MPM-PV 19459 but more worn. They show the trigonid longer and narrower than the talonid, the paralophid curved anteriorly, and lack the entoconid. In MPM-PV 19458 (Fig. 6.16), the hypoconulid is more pronounced than in MPM-PV 19459. The dp4 (MPM-PV 19459; Fig. 6.17-19) is very similar to dp3, with shorter paralophid.

The two-rooted p2 (MPM-PV 19454) lacks the anterolabial portion (Fig. 6.20-22). It is a simple tooth, with a median column on the lingual side that divides the premolar into an anterior and posterior part. It has smooth lingual and labial cingula.

The p3s of MPM-PV 19455 and MPM-PV 19460 (Fig. $6.26,14-15$ respectively), lack an entoconid. The $\mathrm{m} 1$ is heavily worn. It also lacks entoconid and has the trigonid shorter than the talonid. A smooth labial cingulum is evident at the base of trigonid. The m1-m2 (MPM-PV 19455, MPM-PV 19456, MPM-PV 19457, MPM-PV 19459, and MPM-PV 19460; Fig. 6.26, 27-29, 17-19, 13-14 respectively) are structurally similar but the $\mathrm{m} 2$ is slightly larger. The m1s of MPM-PV 19455 and MPM-PV 19456 have shorter and narrower trigonids compared with talonids. The m3 (MPM-PV 19460, MPM-PV 19454, MPM-PV 19457; Fig. 6.13-15, 23-25 respectively) lacks an entoconid (talonid incomplete in MPM-PV 19457). The paralophid is a bit longer than the hypolophulid in MPM-PV 19454, but the two are similar in length in MPM-PV 19460.

Incomplete forelimb and distal elements of a hind limb are preserved in MPM-PV 19460 (Fig. 7.1-12; Tab. 4). The fragment of the humerus preserves only the distal portion, with a broken distal articular surface and only the lateral epicondyle (Fig. 7.1-2). Ulna and radius are not fused (Fig. 7.3-5). The radius is anteroposteriorly flattened, with a smooth concavity on the posterior side where it contacts with the ulna. The proximal articular surface of the humerus has a sigmoidal mediolateral profile and is moderately con- 
cave anteroposteriorly. The proximal parts of the central metapodials (Mt III; Fig. 7.6-7) preserves part of the proximal articular surfaces for the ectocuneiform and cuboid. The distal part of the Mt III (Fig. 7.8) has a well-defined median keel, more pronounced on the posterior side. Two small sesamoids are joined to the posterior distal region of the Mt III; they are kidney-shaped with a slight difference in size (Fig. 7.12). Two fragments of first central phalanges are also present (Fig. 7.9-10). The best preserved is proximodistally elongated, its proximal articular surface is wider than the distal one, and has a medial concavity for the median metapodial keel. The second central phalanx presents a concave proximal surface and the distal trochlea is a bit narrower than the proximal articulation (Fig. 7.11).

Comments. The P1 of MPM-PV 19451 is very similar to that of MACN-A 2996a, MLP 3492, and FMNH P 13193 assigned to T. minusculum, and the associated astragalus coincides morphological and metrically with MACN-A 2974, MACN-A 2983, MACN-A 9048, MACN-A 9049, and FMNH P 13193 of this species (see Tab. 3).

The P1s of MPM-PV 19453 are similar to that of MPMPV 19460 (Fig. 6.10) and a bit smaller than MPM-PV 19451 (Tab. 2). They show a proportional width anterior and posteriorly, similar to P1 of FMNH P 13193 or MPM-PV 3529 that (Cassini et al., 2012) assigned to Th. minusculum. In Tetramerorhinus lucarius (MACN-A 1859-60 and AMNH 9245), instead, the posterior region is wider. In turn, the P1 of Anisolophus australis (YPM-VPPU 15368; Cassini et al., 2012) is more quadrangular and with a smooth median lingual groove.

The presence of a lophoid metaconule in MPM-PV 19452, MPM-PV 19453 and MPM-PV 19460 is characteristic of Thoatherium, whereas this cusp is bunoid in Tetramerorhinus lucarius and A. australis.

Despite the different wear stage of MPM-PV 19452 and MPM-PV 19453, the general shape and size are very similar (Tab. 2). Moreover, MPM-PV 19452 presents great similarities with MACN-A 2996a, MACN-A 9043, and MLP 3682 assigned to Thoatherium minusculum.

The position of the mandibular foramen in MPM-PV 19454 and the presence of two roots allow us to determine this tooth as a p2. It is slightly worn and very similar in size and morphology to the p2 of FMNH P 13193, mentioned
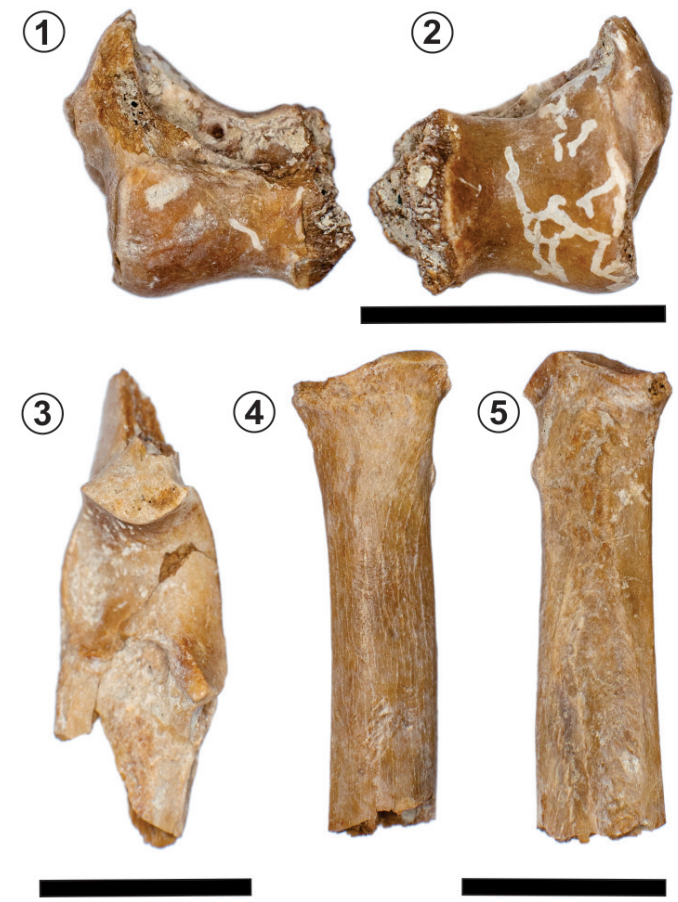

(4)

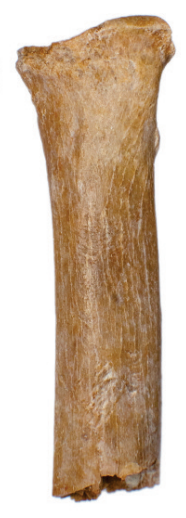

(5)

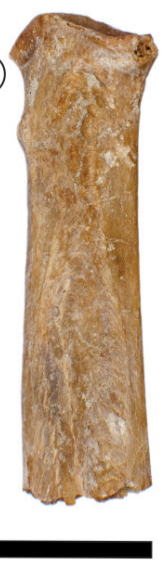

(6)

(6)
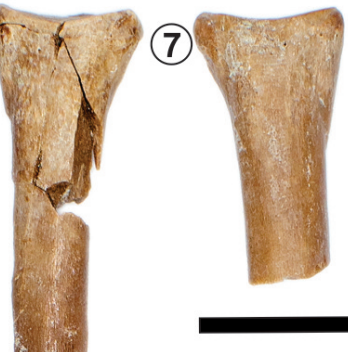

(9)

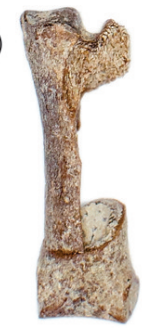

(10)

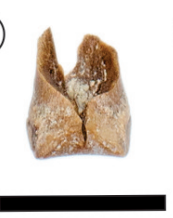

(11)

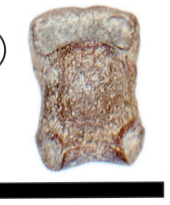

$(8)$

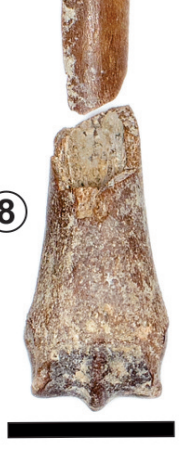

(12)

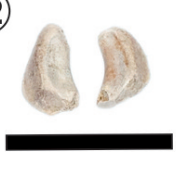

Figure 7. Thoatherium minusculum, MPM-PV 19460; 1-2, distal fragment of right humerus (dorsal and ventral views); 3 , proximal portion of ulna; 4-5, proximal fragment of radius (dorsal and ventral views); 6-8, two proximal fragments and distal epiphysis of Mt III; 9-10, incomplete first phalanges; 11 , complete second phalanx; 12 , sesamoids. Scale bars $=20 \mathrm{~mm}$. 
TABLE 4 - Postcranial dimensions ( $\mathrm{mm}$ ) of Thoatherium minusculum (MPM-PV 19460)

\begin{tabular}{lcc}
\hline Humerus & TDT & 14.0 \\
\hline Ulna & HCS & 16.2 \\
\hline Radius & TDPE & 12.6 \\
& TDD & 13.0 \\
\hline \multirow{2}{*}{ Mclll } & TDPA & 18.3 \\
& DW & 13.0 \\
\hline \multirow{2}{*}{ Phl } & TDDA & 16.8 \\
\hline & $L$ & 38.8 \\
\hline Phll & TDDA & 12.8 \\
\hline \hline & L & 19.8 \\
& TDPA & 13.7 \\
\hline
\end{tabular}

above. The morphology and dimensions of the postcranial remains (MPM-PV 19460) are also very close to those of Th. minusculum FMNH P 13193 (G. Schmidt, pers. observation, 2015).

Genus Diadiaphorus Ameghino, 1887

Type species. Diadiaphorus majusculus Ameghino, 1887. Santa Cruz Formation, Early-Middle Miocene, Province of Santa Cruz, Argentina.

Referred species. Diadiaphorus majusculus Ameghino, 1887.

Diadiaphorus majusculus Ameghino, 1887

Figures 8.1-22; Tables 1, 2 and 5

List of synonymies. See Soria (2001, p. 65).

Referred material. MPM-PV 19461, left m3?; MPM-PV 19462, right m3?; MPM-PV 19463, right M3; MPM-PV 19464, fragment of skull and incomplete postcranial remains, including the articular heads of both humeri, distal fragment of humerus, proximal fragment of ulna, proximal and distal fragments of tibiae, incomplete right calcaneus, distal fragment of metapodial III.

Geographic distribution. Barrancas Blancas (Ea. Aguada
Grande, Ea. Santa Lucía) and Segundas Barrancas Blancas (Ea. Cordón Alto), Río Santa Cruz, Province of Santa Cruz, Argentina.

Stratigraphic distribution. Santa Cruz Formation (EarlyMiddle Miocene, Santacrucian).

Description. On both m3s (Fig. 8.1-2) the trigonid is a bit shorter than the talonid and the lophids are similar in length. The ectoflexid is very deep and the entoconid is absent. MPM-PV 19461 is more complete and preserves a basal cingulum that surrounds the entire tooth.

The upper M3 (MPM-PV 19463; Fig. 8.3; Tab. 2) is moderately worn. It is trapezoidal in occlusal view, with the anterior region wider than the posterior. The parastyle is well developed. The anteroposterior valley is interrupted posteriorly by a bunoid metaconule that becomes fused to the metacone with wear. The anterolingual cingulum is well developed, and reaches the base of the protocone. A hypocone is present.

MPM-PV 19464 preserves the upper right section of the frontal bone, with part of the orbit (Fig. 8.4); posterolaterally, there is a large supraorbital foramen accompanied by another smaller foramen. Two other foramina of different size, are placed medially in the frontal bone. The posterior border of the bone is sinuous.

The heads of the humeri of MPMP-PV 19464 (Tab. 5) are hemispherical and dorsally flattened (Fig. 8.5-6). The distal fragment has both epicondyles poorly preserved. The capitulum occupies a great proportion of the distal articular surface than the trochlea (Fig. 8.7-8).

The ulnar olecranon (Fig. 8.9-11) is well developed, proximally thickened and rugose, as described by Scott (1910) for Diadiaphorus.

The proximal portion of the tibia (Fig. 8.12-13) preserves the medial and lateral intercondyloid tubercles, which form the tibial spine. The distal epiphysis (Fig. 8.1417) preserves the astragalar surface divided in two unequal well-excavated facets.

The fragment of calcaneum (Fig. 8.18-20) has a long and laterally compressed "neck", with a dorsal border narrower than the ventral one. The proximal segment of the tuberosity projects anteriorly.

The distal portion of metapodial III (Fig. 8.21-22) presents a medial keel along the trochlea, on both sides of which 
(1)

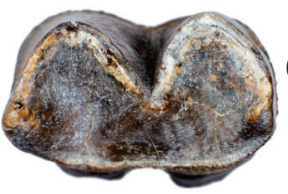

(2)

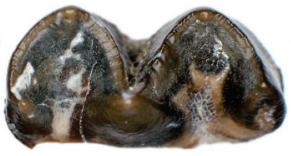

(3)

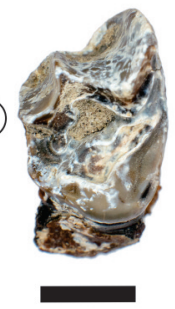

(5)

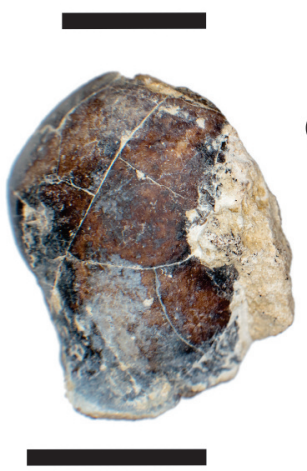

(6)

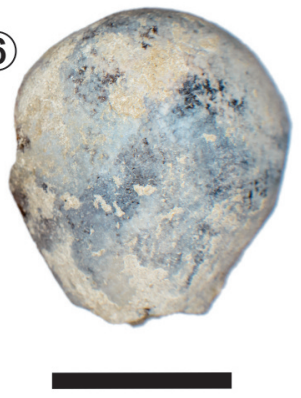

anterior

(4)
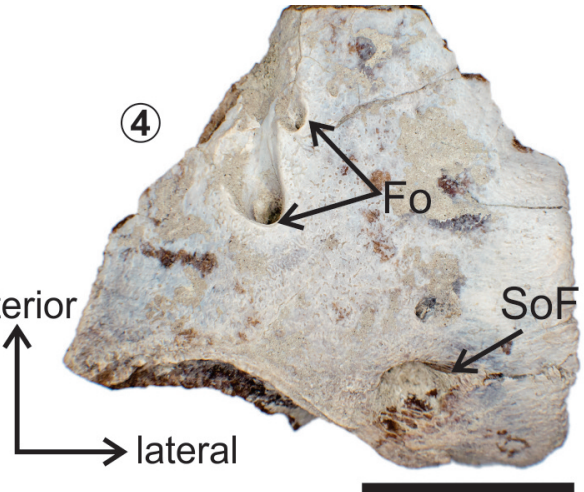

(7)

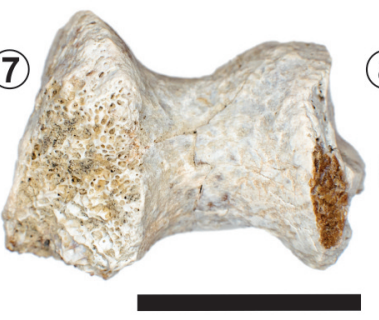

(8)

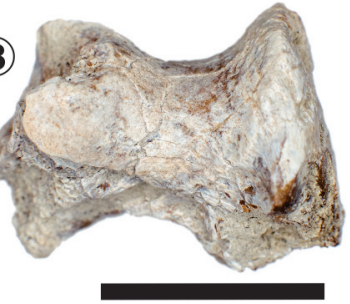

(12)
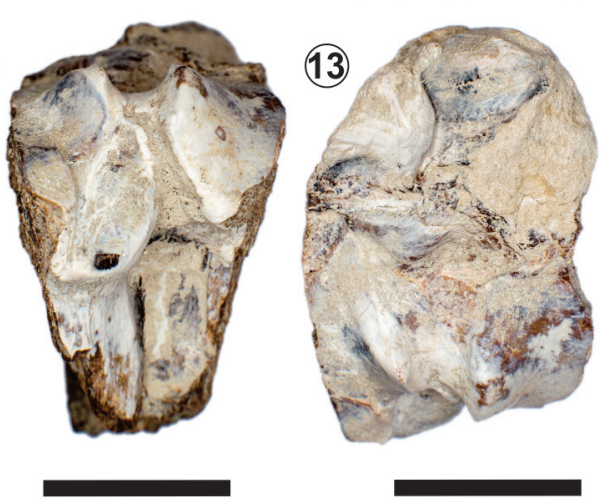

(9)

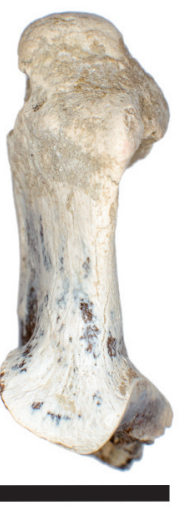

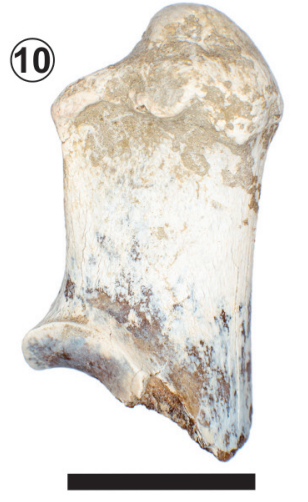

(11)

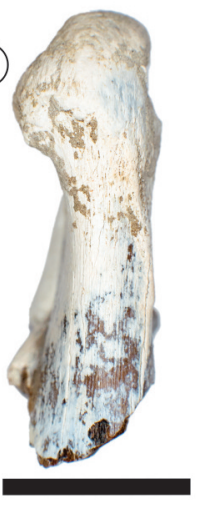

(16)

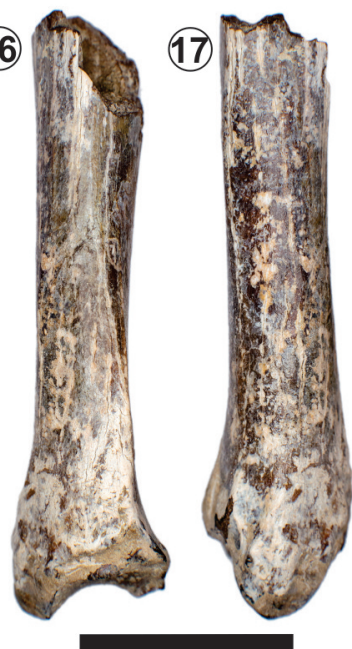

$(18)$

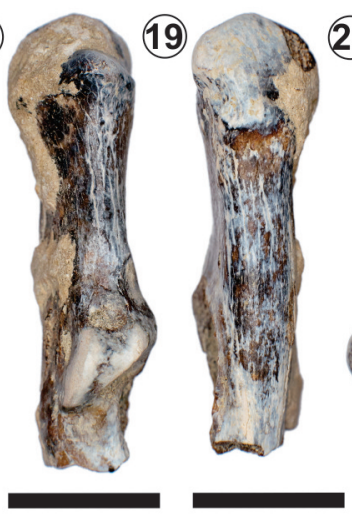

(20)

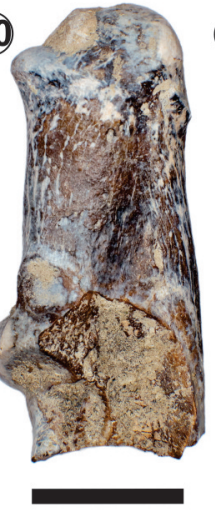

(21)

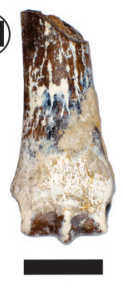

22

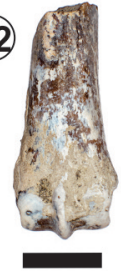

Figure 8. Diadiaphorus majusculus, 1, MPM-PV 19461, left m3?; 2, MPM-PV 19462, right m3?; 3, MPM-PV 19463, right M3; 4-22, MPM-PV 19464, 4, fragment of skull; 5-6, articular head of humeri; 7-8, distal fragment of humerus (dorsal and ventral views); 9-11, proximal fragment of ulna (dorsal, lateral and ventral views); 12-13, proximal fragment of right tibia (posterior and proximal views); 14-17, distal fragment of right tibia (lateral, anterior, posterior and medial views); 18-20, incomplete right calcaneus (dorsal, ventral and medial views); 21-22, distal fragment of metapodial III (dorsal and ventral views). Scale bars: Figs. 1-3=10 mm; Figs. 4-13; 18-22= 20 mm; Figs. 14-17= 40 mm. 


\begin{tabular}{lcc}
\hline $\begin{array}{l}\text { TABLE 5 - Postcranial dimensions (mm) of Diadiaphorus majusculus } \\
\text { (MPM-PV 19464) }\end{array}$ & 25.9 \\
\hline Humerus & TDT & 25.5 \\
\hline Ulna & APDO & 11.0 \\
\hline & TDO & 17.9 \\
& APDD & 20.5 \\
Tibia & TDD & 18.5 \\
& TDDE & 28.9 \\
& APDDA & 30.1 \\
& TDDA & 17.7 \\
Calcaneus & TDTu & 23.5 \\
\hline Central metapodial & APDTu & 23.2 \\
& TDDA & 27.9 \\
& DW & 18.2 \\
\hline
\end{tabular}

are depressions for ligament insertions.

Comments. The absence of entoconid and the lack of tendency to form a third lobe in $\mathrm{m} 3$ are characteristics shared with Diadiaphorus. Moreover, MPM-PV 19461 and MPM-PV 19462 are morphologically and metrically similar to MLP 12320 and MLP 12-325 assigned to Diadiaphorus majusculus (Tab. 1; Soria, 2001: tab. 13). The M3 is also comparable to MACN-A 9198-99, MLP 12-305, MLP 12-306, and AMNH 9270 assigned to D. majusculus (Soria, 2001).

The fragment of skull presents important similarities with AMNH 9270 recognized as D. majusculus (Bergqvist, 2008; Scherer et al., 2009; Corona et al., 2018) and AMNH 14481 (plaster cast, Schmidt, pers. data, 2015) labelled as $D$. majusculus. The foramina in the frontal bone are comparable in morphology, position, and size. The postcranial remains associated to this fragment share size and morphology with D. majusculus (AMNH 9270).

Family MacrauchenIIDAE Gervais, 1855

Subfamily Cramaucheninane Ameghino, 1902

Genus Theosodon Ameghino, 1887
Type species. Theosodon Iydekkeri Ameghino, 1887. Santa Cruz Formation, Early-Middle Miocene, Province of Santa Cruz, Argentina. Referred species. Theosodon lydekkeri, T. Iallemanti, T. garrettorum, T. fontanae, T. gracilis, T. karaikensis, T. pozzii, T.? frenguellii, and "Theosodon" arozquetai.

Theosodon sp.

Figure 9.1-3; Table 6

Referred material. MPM-PV 19465, left and right maxillary fragments with M1 (broken), M2 and erupting M3; MPM-PV 19466, left p4; MPM-PV 19467, left mandibular fragment with $\mathrm{m} 1-\mathrm{m} 2$.

Geographic distribution. Barrancas Blancas (Ea. Santa Lucía) and Segundas Barrancas Blancas (Ea. Cordón Alto), Río Santa Cruz, Province of Santa Cruz, Argentina.

Stratigraphic distribution. Santa Cruz Formation (EarlyMiddle Miocene, Santacrucian).

Description. The M2 of MPM-PV 19465 (Fig. 9.1) is unworn and shows a well-developed metastyle. In occlusal view, the protocone is slightly more lingually placed than the hypocone, but they are relatively closer together than the buccal cusps; a small fossette intervenes between them. The hypocone is mesial to the metacone and the protocone is distal to the paracone. This arrangement gives a trapezoidal appearance to the tooth. The paraconule is smaller than the protocone and is placed opposite the paracone. The trigon basin is shallow. An acute crest extends posterolabially from the hypocone, forming a posterior basin, and a similar crest extends anterolabially from the paraconule, surrounding a little basin. The precingulum is not preserved. In the erupting M3, protocone and hypocone are more separated and the three basins are deeper.

The trigonid of p4 (MPM-PV 19466; Fig. 9.2) is taller than the talonid and its lophids are longer. The metaconid is prominent, with a wide base. Labially, the ectoflexid is deep and a weak cingulum runs at the base. Metaflexid and entoflexid are notably excavated.

The m1-m2 (MPM-PV 19467; Fig. 9.3) are heavily worn. The $\mathrm{m} 1$ is shorter than $\mathrm{m} 2$, and shows the entoconid, which also is present on $\mathrm{m} 2$. Labial cingula are continuous at the base of the teeth whereas lingual cingula are discontinuous, present only anteriorly and posteriorly (observable in $\mathrm{m} 2$ ). 

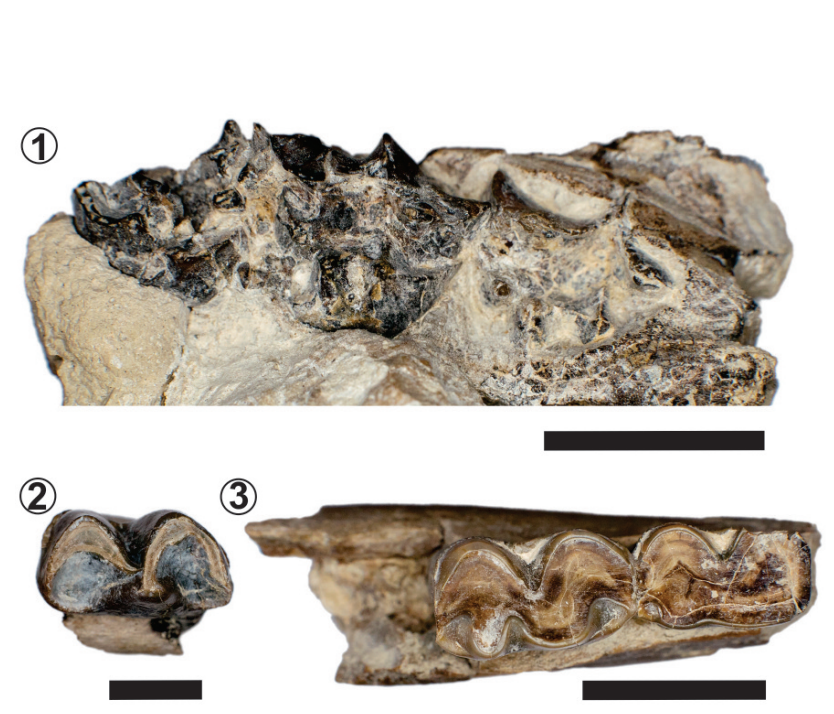

Figure 9. Theosodon sp.; 1, MPM-PV 19465, left maxillary fragment with M1 (broken), M2 and erupting M3; 2, MPM-PV 19466, left p4; 3, MPM-PV 19467, left mandibular fragment with $\mathrm{m} 1-\mathrm{m} 2$. Scale bars: Figs. 1 and $3=20 \mathrm{~mm}$; Fig. $2=10 \mathrm{~mm}$.

Comments. The lack of metaconule in the M2 of MPM-PV 19465 coincides with Theosodon (Soria, 1981) and differs from Cramauchenia (Soria, 1981: fig. 2A). MPM-PV 19465 is morphologically similar to MACN-A 9269-88 (T. lydekkeri), FMNH P 13175 (T. garrettorum), and FMNH P 13187 (T. lallemanti). Concerning size, MPM-PV 19465 falls in the range of these species of Theosodon, being nearer to T. Iallemanti after Scott's (1910) measurements.

Regarding lower teeth (m1-m2), Cramauchenia and Theosodon do not show significant morphological differences (Soria, 1981). However, the lingual position of the paraconid in m2 of MPM-PV 19467 is closer to Theosodon than to Cramauchenia, in which this cusp is more labially placed (Soria, 1981: plate 2A). Moreover, the morphological similarities of MPM-PV 19466 and MPM-PV 19467 with a specimen labelled as Theosodon sp. (MLP 12-381, G. Schmidt, pers. data, 2010) are evident. The measurements of p4, m1 and $\mathrm{m} 2$ (Tab. 6) exceed those assigned to Cramauchenia (Soria, 1981: 14) and are close to those of T. gracilis (MACNA 2521, lectotype, MACN-A 9297, and AMNH 9230; Scott, 1910; Soria, 1981).
TABLE 6 - Dental dimensions (mm) of Theosodon sp.

\begin{tabular}{|c|c|c|c|c|}
\hline & & MPM-PV 19465 & MPM-PV 19466 & MPM-PV 19467 \\
\hline \multirow[t]{2}{*}{ M2 } & $L$ & 23.9 & & \\
\hline & $w$ & 18.2 & & \\
\hline \multirow[t]{2}{*}{ M3 } & $L$ & $20.5^{*}$ & & \\
\hline & W & $17.8^{*}$ & & \\
\hline \multirow[t]{2}{*}{$p 4$} & $L$ & & 23.2 & - \\
\hline & $w$ & & 12.7 & - \\
\hline \multirow[t]{2}{*}{$m 1$} & $L$ & & - & 18.7 \\
\hline & w & & - & $12.0^{*}$ \\
\hline \multirow[t]{2}{*}{$m 2$} & $L$ & & - & 21.2 \\
\hline & W & & - & 13.1 \\
\hline \multicolumn{5}{|c|}{ *Approximate } \\
\hline
\end{tabular}

\section{FINAL REMARKS}

The new remains of Litopterna recorded from the Río Santa Cruz correspond to Proterotheriidae and Macraucheniidae. Within Proterotheriidae, six species were recognized: Anisolophus australis, A. floweri, Tetramerorhinus lucarius, Te. cingulatum, Thoatherium minusculum, and Diadiaphorus majusculus. The majority of these specimens come from Segundas Barrancas Blancas (Ea. Cordón Alto). Thoatherium minusculum and D. majusculus were originally included in the taxa nominated by Ameghino (1887) from the Río Santa Cruz.

Soria (2001) assigned some specimens from the Río Santa Cruz to Anisolophus australis, Thoatherium minusculum and Tetramerorhinus mixtum. The latter has not been identified within the recent new collection; instead, we recognized Te. Iucarius and Te. cingulatum. It is worth to mention that different species within the same genus (e.g., Anisolophus, Tetramerorhinus) are recognized based mainly on size, but some overlap exists, making it difficult to achieve an accurate assignment of individual specimen.

Macraucheniidae is represented by Theosodon, but as- 
signment to a species was not possible due to the poorly preserved material. Theosodon remains were recovered from Barrancas Blancas and Segundas Barrancas Blancas (Ea. Santa Lucía and Ea. Cordón Alto, respectively). This genus should be revised in order to analyze its taxonomic richness during the Santacrucian. As it happens with some proterotheriids, several species of Theosodon are differentiated only by size.

The abundance of proterotheriid specimens (39) from the Río Santa Cruz localities exceeds by far that of macraucheniids (one specimen from Segundas Barrancas Blancas and two from Barrancas Blancas). This agrees with data published by Tauber (1999: tab. 1) where the presence of proterotheriids (eight records) surpasses those of macraucheniids (two records) in the Santacrucian localities prospected between the Río Coyle and Río Gallegos (Province of Santa Cruz). Kramarz and Bond (2005) pointed out the low relative abundance of Santacrucian representatives of both families in the MACN Ameghino collection, where they found that only $24 \%$ of the litoptern remains in that collection belong to Macraucheniidae. In the same contribution, the authors highlighted that macraucheniids remains are also scarce for the levels of the Pinturas Formation (Early Miocene, Province of Santa Cruz).

In summary, the systematic of litopterns of the Santa Cruz Formation requires an update. The new remains from the Río Santa Cruz reported here, as well as others recently recovered from other Santacrucian localities, particularly from the Atlantic coast (Cassini et al., 2012; Vizcaíno et al., 2012), will be valuable to clarify the taxonomy of this peculiar group of South American extinct ungulates.

\section{ACKNOWLEDGEMENTS}

To the editors, M.S. Bargo, S.F. Vizcaíno, J.C. Fernicola, and R.F. Kay, for inviting us to participate in this volume; to the reviewers ( $E$. Cerdeño and an anonymous reviewer) for their useful comments; to the Dirección de Patrimonio Cultural, and Museo Regional Provincial Padre M. J. Molina (Río Gallegos, Province of Santa Cruz) for permission and support for fieldwork; to C.M. Vega for providing photographs; to A. Kramarz, M. Ezcurra and L. Chornogubsky (MACN), M. Reguero and A. Scarano (MLP), W. Simpson (FMNH), J. Galkin (AMNH), for making available the collections under their care. This is a contribution to projects PIP-CONICET 00781, UNLP 11/N867, PICT 2013-0389 and 2017-1081, National Science Foundation grants 0851272 and 1348259 to R. F. Kay, and National Geographic Society grant 9167-12.

\section{REFERENCES}

Ameghino, F. 1887. Enumeración sistemática de las especies de mamíferos fósiles coleccionados por Carlos Ameghino en los terrenos eocenos de Patagonia Austral y depositados en el Museo La Plata. Boletín del Museo de La Plata 1: 1-26.

Ameghino, F. 1889. Contribución al conocimiento de los mamíferos fósiles de la República Argentina. Actas de la Academia Nacional de Ciencias de Córdoba 6: 1-1027.

Ameghino, F. 1891. Nuevos restos de mamíferos fósiles descubiertos por Cárlos Ameghino en el Eoceno inferior de la Patagonia austral. Especies nuevas, adiciones y correcciones. Revista Argentina de Historia Natural 1: 289-328.

Ameghino, F. 1894. Enumération synoptique des espèces de mammifères fossiles des formations éocènes de Patagonie. Boletín de la Academia Nacional de Ciencias de Córdoba 13: 259-455.

Ameghino, F. 1899. Sinopsis geológico-paleontológica. Suplemento (Adiciones y correcciones). Imp. La Libertad, La Plata, 13 p.

Ameghino, F. 1902. Première contribution à la connaissance de la faune mammalogique des couches à Colpodon. Boletín de la Academia Nacional de Ciencias de Córdoba 17: 71-138.

Ameghino, F. 1904a. Recherches de morphologie phylogénétique sur les molaires supérieures des ongulés. Anales del Museo Nacional de Buenos Aires 9: 1-541.

Ameghino, F. 1904b. Nuevas especies de mamíferos cretáceos y terciarios de la República Argentina. Anales de la Sociedad Científica Argentina 57: 162-175; 327-341.

Bergkvist, L.P. 2008. Postcranial skeleton of the upper Paleocene (Itaboraian) 'Condylarthra' (Mammalia) of Itaboraí Basin, Brazil. In: E.J. Sargis, and M. Dagosto (Eds.), Mammalian evolutionary morphology: a tribute to Frederick S. Szalay. Vertebrate Paleobiology and Paleoanthropology Series, Netherlands, p. 107-133.

Bonaparte, J.F., and Morales, J. 1997. Un primitivo Notonychopidae (Litopterna) del Paleoceno inferior de Punta Peligro, Chubut, Argentina. Estudios geológicos 53: 263-274.

Bond, M. 1986. Ungulados fósiles de Argentina: evolución y paleoambientes. $4^{\circ}$ Congreso Argentino de Paleontología y Bioestratigrafía (Mendoza), Actas 2: 173-185.

Bond, M. 1999. Quaternary native ungulates of Southern South America. A synthesis. In: J. Rabassa, and M. Salemme (Eds.), Quaternary of South America and Antarctic Peninsula. Rotterdam, Netherlands, p. 177-205.

Bond, M., Cerdeño, E., and López, G. 1995. Los ungulados nativos de América del Sur. In: M.T. Alberdi, G. Leone, and E.P. Tonni (Eds.), Evolución biológica y climática de la región Pampeana durante los últimos cinco millones de años. Un ensayo de correlación con el Mediterráneo occidental. Monografías del Museo Nacional de Ciencias Naturales, CSIC, Madrid, p. 259-275.

Burmeister, G. 1879. Description physique de la République Argentine d'après des observations personnelles et étrangères. 3 (animaux vertébrés 1: Mammifères vivants et éteintes). P.E. Coni, Buenos Aires, $555 \mathrm{p}$.

Burmeister, G. 1885. Examen crítico de los mamíferos y reptiles fósiles denominados por Don Augusto Bravard. Anales Museo Nacional de Buenos Aires 3: 95-173.

Cabrera, A., and Kraglievich, L. 1931. Diagnosis previas de los ungulados fósiles de la Formación Arroyo Chasicó. Notas del Museo La Plata 1: 107-113.

Cassini, G.H., Cerdeño, E., Villafañe, A.L., and Muñoz, N.A. 2012. Paleobiology of Santacrucian native ungulates (Meridiungulata: Astrapotheria, Litopterna, and Notoungulata). In: S.F. Vizcaíno, R.F. Kay, and M.S. Bargo (Eds.), Early Miocene Paleobiology in 
Patagonia: High-Latitude Paleocommunities of the Santa Cruz Formation. Cambridge University Press, Cambridge, p. 243-286.

Cifelli, R.L., and Guerrero, J. 1997. Litopterns. In: R.F. Kay, R.H. Madden, R.L. Cifelli, and J.J. Flynn (Eds.), Vertebrate Paleontology in the Neotropics: The Miocene Fauna of La Venta, Colombia. Smithsonian Institution Press, Washington and London, p. 289-302.

Corona, A., Perea, D., and Ubilla, M. 2018. The humerus of Proterotheriidae (Mammalia, Litopterna) and its systematic usefulness: the case of "Proterotherium berroi" Kraglievich, 1930. Ameghiniana 55: 150-161.

Corona, A., Perea, D., and Ubilla, M. 2019. A new genus of Proterotheriinae (Mammalia, Litopterna) from the Pleistocene of Uruguay. Journal of Vertebrate Paleontology doi: 10.1080/ 02724634.2019 .1567523

Croft, D.A. 2016. Horned Armadillos and Rafting Monkeys: The Fascinating Fossil Mammals of South America. Indiana University Press, Bloomington, $304 \mathrm{p}$.

Croft, D.A., Flynn, J.J., and Wyss, A.R. 2004. Notoungulata and Litopterna of the early Miocene Chucal Fauna, Northern Chile. Fieldiana Geology 50: 1-52.

Cuitiño, J.I., Fernicola, J.C., Kohn, M., Trayler, R., Naipauer, M., Bargo, M.S., Kay, R.F., and Vizcaíno, S.F. 2016. U-Pb geochronology of the Santa Cruz Formation (early Miocene) at the Río Bote and Río Santa Cruz (southernmost Patagonia, Argentina): implications for the correlation of fossil vertebrate localities. Journal of South American Earth Sciences 70: 198-210.

Cuitiño, J.I., Fernicola, J.C., Raigemborn, M.S., and Krapovickas, V. 2019. Stratigraphy and depositional environments of the Santa Cruz Formation (Early-Middle Miocene) along the Río Santa Cruz, Southern Patagonia, Argentina. In: J.C. Fernicola, M.S. Bargo, S.F. Vizcaíno, and R.F. Kay (Eds.), Early-Middle Miocene Paleontology in the Río Santa Cruz, Southern Patagonia, Argentina. 130 years since Ameghino, 1887. Publicación Electrónica de la Asociación Paleontológica Argentina 19: 14-33.

Delupi de Bianchini, L.H., and Bianchini, J.J. 1971. Revisión de los Proterotheriinae (Mammalia, Litopterna) del "Mesopotamiense". Ameghiniana 8: 1-23.

Dozo, M.T., and Vera, B. 2010. First skull and associated postcranial bones of Macraucheniidae (Mammalia, Litopterna) from the Deseadan SALMA (late Oligocene) of Cabeza Blanca (Chubut, Argentina). Journal of Vertebrate Paleontology 30: 1818-1826.

Fernicola, J.C. 2011. Implicancias del conflicto Ameghino-Moreno sobre la colección de mamíferos fósiles realizada por Carlos Ameghino en su primera exploración al río Santa Cruz, Argentina. Revista del Museo Argentino de Ciencias Naturales 13: 41-57.

Fernicola, J.C., Bargo, M.S., Vizcaíno, S.F., and Kay, R.F. 2019. Historical background for a revision of the paleontology of the Santa Cruz Formation (Early-Middle Miocene) along the Río Santa Cruz, Patagonia, Argentina. In: J.C. Fernicola, M.S. Bargo, S.F. Vizcaíno, and R.F. Kay (Eds.), Early-Middle Miocene Paleontology in the Río Santa Cruz, Southern Patagonia, Argentina. 130 years since Ameghino, 1887. Publicación Electrónica de la Asociación Paleontológica Argentina 19: 1-13.

Fernicola, J.C., Cuitiño, J.I., Vizcaíno, S.F., Bargo, M.S., and Kay, R.F., 2014. Fossil localities of the Santa Cruz Formation (Early Miocene, Patagonia, Argentina) prospected by Carlos Ameghino in 1887 revisited and the location of the Notohippidian. Journal of South American Earth Sciences 52: 91-107.

Flynn, J.J., and Wyss, A.R. 1998. Recent advances in South American mammalian paleontology. Tree 11: 449-454.

Forasiepi, A.M., MacPhee, R.D.E., Hernández Del Pino, S., Schmidt,
G.I., Amson, E., and Grohé, C. 2016. Exceptional skull of Huayqueriana (Mammalia, Litopterna, Macraucheniidae) from the late Miocene of Argentina: anatomy, systematics, and paleobiological implications. Bulletin of the American Museum of Natural History 404: 1-76.

Gaudry, A. 1904. Fossiles de Patagonie. Dentition de quelques mammifères. Mémoires de la Société Géologique de France. Paléontologie 12: 1-27.

Gaudry, A. 1906. Fossiles de Patagonie: les attitudes de quelques animaux. Annales de Paléontologie 1: 1-42.

Gervais, P. 1855. Recherches sur les mammifères fossiles de I'Amérique méridionale. Comptes Rendus de l'Académie des Sciences 40: 1112-1114.

Kraglievich, L. 1930. La formación Friaseana del río Frías, río Fénix, Laguna Blanca, etc., y su fauna de Mamíferos. Physis 10: 127-161.

Kramarz, A.G., and Bond, M. 2005. Los Litopterna (Mammalia) de la Formación Pinturas, Mioceno Temprano-Medio de Patagonia. Ameghiniana 42: 611-625.

Luna, C.A., Schmidt, G.I., and Ochoa, J.G. 2015. Nuevos registros de Neolicaphrium recens Frenguelli (Litopterna, Proterotheriidae) procedentes de Corralito (Pleistoceno tardío-Holoceno temprano), Córdoba, Argentina. Ameghiniana 53 Abstracts Supplement: 20R.

Lydekker, R. 1894. Contributions to a knowledge of the fossil vertebrates of Argentina. 3. A study of extinct Argentine ungulates. Anales del Museo de La Plata, Paleontología 2: 1-91

McGrath, A.J., Anaya, F., and Croft, D.A, 2018. Two new macraucheniids (Mammalia: Litopterna) from the late middle Miocene (Laventan South American Land Mammal Age) of Quebrada Honda, Bolivia. Journal of Vertebrate Paleontology doi 10.1080/02724634.2018.1461632

McGrath, A., Flynn, J.J., and Wyss, A.R. 2019. Proterotheriids and macraucheniids (Litopterna: Mammalia) from the Pampa Castillo Fauna, Chile (early Miocene, Santacrucian SALMA) and a new phylogeny of Proterotheriidae. Journal of Systematic Palaeontology doi: 10.1080/14772019.2019.1662500

Mercerat, A. 1891. Sinopsis de la Familia Bunodontheriidae (Eoceno de Patagonia) conservada en el Museo de La Plata. Revista del Museo de la Plata 1: 447-471.

Mones, A. 1986. Paleovertebrata Sudamericana. Catálogo sistemático de los Vertebrados fósiles de América del Sur. Parte I. Lista preliminar y Bibliografía. Courier Forschunginstitut Senckenberg 82: 1-625.

Pascual, R., Ortiz-Jaureguizar, E., and Prado, J.L. 1996. Land mammals: paradigm for Cenozoic South American geobiotic evolution. In: G. Arratia (Ed.), Contribution of Southern South America to Vertebrate Paleontology. Munchner Geowissenshaftliche Abhandlungen, Munich, p. 265-319.

Roth, S. 1899. Aviso preliminar sobre mamíferos mesozoicos encontrados en Patagonia. Revista del Museo de La Plata 9: 381388.

Scherer, C.S., Pitana, V.G., and. Ribeiro, A.M. 2009. Proterotheriidae and Macraucheniidae (Litopterna, Mammalia) from the Pleistocene of Rio Grande do Sul State, Brazil. Revista Brasileira de Paleontologia 12: 231-246.

Schmidt, G.I., and Ferrero, B.S. 2014. Taxonomic reinterpretation of Theosodon hystatus Cabrera and Kraglievich, 1931 (Litopterna, Macraucheniidae) and phylogenetic relationships of the family. Journal of Vertebrate Paleontology 34: 1231-1238.

Scott, W.B. 1910. Mammalia of the Santa Cruz beds. Part I: Litopterna. Reports of the Princeton University Expedition to 
Patagonia. In: W.B. Scott (Ed.), Reports of the Princeton University Expedition to Patagonia (1896-1899). Princeton University, E. Schweizerbart'sche Verlashandlung, Stuttgart, p. 1-156.

Soria, M.F. 1981. Los Litopterna del Colhuehuapense (Oligoceno Tardío) de la Argentina. Revista del Museo Argentino de Ciencias Naturales "Bernardino Rivadavia", Serie Paleontología 3: 1-54.

Soria, M.F. 2001. Los Proterotheriidae (Mammalia, Litopterna): sistemática, origen y filogenia. Monografías del Museo Argentino de Ciencias Naturales "Bernardino Rivadavia" 1: 1-167.

Tauber, A.A. 1999. Los vertebrados de la Formación Santa Cruz (Mioceno inferior-medio) en el extremo sureste de la Patagonia y su significado paleoecológico. Revista Española de Paleontología 14: 173-182.

Tonni, E.P. 1990. Mamíferos del Holoceno de la Provincia de Buenos Aires. Paulacoutiana 4: 2-21.

Ubilla, M., Perea, D., Bond, M., and Rinderknecht, A. 2011. The first cranial remains of the Pleistocene proterotheriid Neolicaphrium Frenguelli, 1921 (Mammalia, Litopterna): a comparative approach. Journal of Vertebrate Paleontology 31: 193-201.

Villafañe, A.L., Ortiz-Jaureguizar, E., and Bond, M. 2006. Cambios en la riqueza taxonómica y en las tasas de primera y última aparición de los Proterotheriidae (Mammalia, Litopterna) durante el Cenozoico. Estudios Geológicos 62: 155-166.

Vizcaíno, S.F. 2011. Cartas para Florentino desde la Patagonia. Crónica de la correspondencia édita entre los hermanos Ameghino (1887-1902). In: J.C. Fernicola, A.R. Prieto, and D.G. Lazo (Eds.), Vida y obra de Florentino Ameghino. Publicación Especial de la Asociación Paleontológica Argentina 12: 51-67.

Vizcaíno S.F., Kay, R.F., and Bargo M.S. 2012. Background for a paleoecological study of the Santa Cruz Formation (late Early Miocene) on the Atlantic Coast of Patagonia. In: S.F. Vizcaíno, R.F. Kay, and M.S. Bargo (Eds.), Early Miocene Paleobiology in Patagonia: High-latitude Paleocommunities of the Santa Cruz Formation. Cambridge University Press, Cambridge, p. 1-22.

Zittel, K.A. von. 1893. Handbuch der Palaeontologie. Abteilung I. Palaeozoologie. Bd. IV. Vertebrata (Mammalia), Munich, 799 p.

Zurita-Altamirano, D., Buffetaut, E., Forasiepi, A.M., Kramarz, A., Carrillo, J.D., Aguirre-Fernández, G., Carlini, A.A., Scheyer, T.M., and Sánchez-Villagra, M.R. 2019. The Allemann collection from the Santa Cruz Formation (late early Miocene), Argentina, in Zurich, Switzerland. Swiss Journal of Palaeontology doi: 10.1007/s13358-019-00185-5

Doi: 10.5710/PEAPA.13.08.2019.290

Recibido: 29 de marzo 2019

Aceptado: 13 de agosto 2019
Appendix 1. List of the revised material of Litopterna.

\section{Proterotheriidae}

\section{Anisolophus australis}

MACN-PV 2417, holotype, incomplete palate with left P2-M3 without labial sides, and right P2-P4.

MACN-A 8669, holotype of Proterotherium intermedium (junior synonym of $A$. australis), right mandible with p3-m3.

MACN-A 3107, right M1-M3.

YPM-VPPU 15368, incomplete skull with left I, and P1-M3, and right P1-M3.

\section{Anisolophus floweri}

MACN-A 8999, incomplete skull with left D1-D4-M1-M2, and right $\mathrm{M} 1-\mathrm{M} 2$.

MACN-A 9003-12, holotype of Licaphrium pyramidatum (junior synonym of $A$. floweri), left $\mathrm{P} 4-\mathrm{M} 3$, right incomplete $\mathrm{P} 4, \mathrm{M} 1$ and $\mathrm{M} 2$ (isolated), right $\mathrm{p} 4, \mathrm{~m} 2-\mathrm{m} 3$; and postcranial remains. MACN-A 3085, right mandible with p2-m1 (m1 broken). MLP 12-289, left mandibular fragment with m2-m3.

MLP 82-IV-3-3, right m3.

MLP 82-IV-3-4, left m3 (2).

PIMUZ A/V 5293, left m1.

YPM-VPPU 15711, holotype of Licaphrium pyneanum (junior synonym of $A$. floweri), skull almost complete with right $\mathrm{P} 2-\mathrm{M} 3$ and left P3-M3 (M3 erupting).

YPM-VPPU 15309, right mandibular fragment with p4-m3.

Anisolophus minusculus

MACN-A 9001b, right maxilla with D4-M1-2.

Tetramerorhinus lucarius

AMNH 9245, skull.

MACN-A 1855, left maxillary fragment with P3-M3.

MACN-A1859-60, incomplete skull with both series complete, and mandible with alveoli of internal incisives, external incisives, and $\mathrm{p} 1-\mathrm{m} 3$ of both sides.

MLP 12-250, incomplete mandible with left $\mathrm{p} 1$ and right $\mathrm{p} 1-\mathrm{m} 2$. MLP 12-337, right p4-m1.

PIMUZ A/V 5434, isolated premolars and molars, including left dp3 or dp4, p3 or p4, left and right m1 or m2.

\section{Tetramerorhinus cingulatum}

MACN-A 8667-68, holotype of Proterotherium divortium (junior synonym of Te. cingulatum), left maxillary fragment with P4-M3, mandible with symphysis, and right and left p1-p3.

MACN-A 3106, left mandibular fragment with p4-m3.

\section{Tetramerorhinus prosistens}

MACN-A 11626, holotype, right maxillary fragment with P4-M3, left P3-P4, M2-M2; right mandible with p2, p4-m3, left mandible with $\mathrm{p} 3-\mathrm{p} 4$, incomplete $\mathrm{m} 1$ ?, and $\mathrm{m} 3$.

\section{Tetramerorhinus mixtum}

MACN-A 8663, holotype of Proterotherium pyramidatum (junior synonym of Te. mixtum), palate with incisives, right P3-M3, and left P1-M3.

MACN-A 5987, mandible with right $c-m 3$ and left p1-m3.

MACN-A 3068-69, right mandible with p4-m3 and left m1-m3. Tetramerorhinus fleaglei

MACN SC 129-30, holotype, right and left P4-M2.

Thoatherium minusculum

FMNH P 13193, skull, mandible and postcranial remains.

MACN-A 2996a, palate with right and left P1-M3. 
MACN-A 2974, astragalus.

MACN-A 2983, astragalus.

MACN-A 9048, astragalus.

MACN-A 9049, astragalus.

MACN-A 9043, palate with left P2-M3, and right P4 (incom-

plete)-M3.

MPM-PV 3492, skull.

MPM-PV 3682, skull.

Diadiaphorus majusculus

AMNH 9270, skull and postcranial remains.

AMNH 14481, skull.

MACN-A 9198-99, right maxilla with P1-M3.

MLP 12-305, incomplete skull with right I and P1-M3, and left P1-P4.

MLP 12-306, palate with right and left P1-M3.

MLP 12-320, complete mandible.
MLP 12-325, right mandibular fragment with m2-m3.

Macraucheniidae

Theosodon lydekkeri

MACN-A 9269-88, skull and mandible.

Theosodon garrettorum

FMNH P 13175, skull.

Theosodon lallemanti

FMNH P 13187, skull poorly preserved with left P3-M3, and right $\mathrm{P} 2-\mathrm{P} 3, \mathrm{M} 2-\mathrm{M} 3$.

Theosodon gracilis

AMNH 9230, skull and incomplete mandible.

MACN-A 2521, lectotype, mandible with m1-m2? of both sides.

MACN-A 9297, right mandibular fragment with p1-m3.

Theosodon sp.

MLP 12-381, incomplete mandible with left i1-c, and right i1-p2, p4-m3. 